\title{
Effect of Dietary Magnesium and Calcium on Reducing the Risk of Atherosclerosis in High-Fat Diet Fed Rats
}

\author{
Rubaba Karim*, Tanjina Islam, Shafiul Islam Khan, Sultana Jahan, Masum Billah, Ashfia Fatima Khan, Taslima \\ Begum and Rayhana Begum
}

Department of Pharmacy, Primeasia University, Bangladesh

Submission: May 14, 2018; Published: June 05, 2018

*Corresponding author: Rubaba Karim, Department of Pharmacy, Primeasia University, Dhaka-1213, Bangladesh, Tel: +8801716608253; Email: rubkam.85@gmail.com

\begin{abstract}
Background: Magnesium and calcium have competing effects on various metabolic pathways. Magnesium deficiency is associated with a high frequency of cardiac arrhythmias, hypertension, and myocardial death. Calcium supplementation may promote the incidence of atherosclerosis via arterial calcification. A study from 1959 revealed that incorporating a high-magnesium with moderate-calcium diet to laboratory animals prevented heart and kidney damage. It was observed that a high calcium supplementation did not cause any heart defects as long as high magnesium diet is fed to the animals. Under low calcium diet, magnesium had no cardioprotective effects. With this regards, the present study was designed to determine suitable combined doses of dietary Magnesium and Calcium to reduce the risk of atherosclerosis.
\end{abstract}

Materials and Methods: Wister Albino rats were divided into different groups $(n=4)$ based on their diets (Normal diet, High-Fat Diet (HFD)/atherogenic diet, HFD+Mg/Ca salts). HFD induced atherogenic rats were treated with either single or combined doses of MgCO3 (200, 400 and $600 \mathrm{mg} / \mathrm{kg} /$ day) and CaCO3 (500, 1000 and $1500 \mathrm{mg} / \mathrm{kg} /$ day) salts in diet for 12 weeks. The extent of atherosclerosis in experimental animals were analyzed by measuring body weight, systolic blood pressure (SBP) and serum lipid levels (cholesterol, triglyceride, LDL, HDL). Histopathology of the aorta, kidney and liver of atherogenic model was performed. The mean values of results of the treatment groups were compared with Ca-deficit groups of atherogenic rats by using ANOVA and Dunnet's test.

Results: Groups XV (HFD+Ca1000mg+Mg600 mg) and XVII (HFD+Ca1500mg+Mg 600mg) showed significant decrease in serum lipids and SBP when compared with Mg-rich diet groups $(200,400 \& 600 \mathrm{mg} / \mathrm{kg} /$ day $)(\mathrm{p}<0.01)$. Histopathological report of aorta, kidney and liver provided evidence of hypolipidemia and reduced risk of atherosclerosis in treated animals.

Conclusion: Our present investigation indicates that a combination of high magnesium and moderate to high calcium salts in diet shows potential response against atherosclerosis..

Keywords: Atherosclerosis; High-fat diet; Dietary Magnesium; Dietary Calcium; Atherogenic rats.

\section{Introduction}

Atherosclerosis is a complex chronic arterial disease that results from the deposition of lipids within the arterial walls which leads to formation of characteristic plaques making the arteries narrower, harder or completely blocked. The rupture of these plaques causes local thrombosis, leading to occlusion of the affected artery [1]. The principle clinical manifestations of the disease include ischemic heart disease, ischemic stroke and peripheral arterial disease [2]. This has become the significant cause of vascular disease worldwide and number one cause of global mortality [3]. According to WHO report, around 17.7 million people died from cardiovascular disease in 2015 which represents $31 \%$ of the total global deaths [4]. The major risk factor for the development of atherosclerosis is hypercholesterolemia, indicating elevation of body's Total Cholesterol (TC) and LowDensity Lipoprotein Cholesterol (LDL-C) levels [4]. Therefore, foods rich in saturated fat and cholesterol are particularly responsible for the surge of circulating cholesterol levels [5].

It has been evidently understood from the previous studies that both Magnesium and Calcium play significant role in cardiac function. Accumulation of calcium in the arterial wall facilitate in development of atherosclerotic plaque [6]. It was reported that calcium rich diet increases both intra- and extracellular calcium resulting high level of cytosolic calcium that increases cardiac smooth muscle contraction [7-10]. This eventually elevates 
the frequency of cardiac arrhythmias and hypertension. As a result it was found that $\mathrm{Ca}$ antagonists have an antiatherogenic effect $[11,12]$. On the other hand, Mg antagonizes the effect of Ca in raising the velocity of vascular and cardiac smooth muscle contraction [13]. It was reported that $\mathrm{Mg}$ supplementation decreases arterial blood pressure and the rate of cardiac arrhythmias after myocardial infarction [14-17]. Therefore, adequate level of magnesium is required for proper function of heart muscle. Moreover, studies revealed that Mg suppresses the development of atherosclerotic lesions in the aorta by blocking the intracellular entry of Ca [18]. It was also found that the rate of cardiovascular mortality inversely correlates with urinary excretion of $\mathrm{Mg}$ indicating that $\mathrm{Mg}$ intake may inhibit the development of atherosclerosis $[18,19]$. This evidence was supported by one of the previous findings that showed extensive lipid deposition in the aortas of Mg-deficient, high cholesterol fed animals resulting hardening of the arteries [20]. Hence, it is evident from previous investigations using experimental animals that magnesium supplementation inhibited lipid deposition in the aortic walls (i.e. inhibited plaque formation) [18]. However, the detail mechanism of regulation by Mg is yet to be fully understood [21].

A recent article of Dr. Russell Blaylock [22] mentioned about the close relation of magnesium supplementation with serum levels of LDL (potentially harmful) cholesterol and total cholesterol. Magnesium reportedly reduced bad cholesterol and increased good cholesterol (high density lipoprotein) in blood [23-26]. Dr. Blaylock [22] supported such hypothesis with respect to the fact that being a powerful anti-inflammatory element, magnesium would help prevent cholesterol from oxidizing which may explain its role in diminishing atherosclerotic plaque in experimental animals [22]. A remarkable study from 1959 demonstrated the interrelationship between calcium and magnesium and atherosclerosis [27]. Their investigation not only revealed the role of magnesium in lowering arterial lipid and calcium accumulation but also its contribution in preventing
Ca deposition in the kidneys of animals fed with atherogenic diet [27]. An interesting observation was found from the same study which showed that when $\mathrm{Ca}$ intake was very low, $\mathrm{Mg}$ failed to protect heart and kidneys [27]. This indicated the fact that high-calcium intake may not cause problems as long as the magnesium intake is high.

With respect to the earlier observation, Dr. Blaylock [22] suggested in his article [22] that one must have an adequate intake of calcium in order to stimulate the protective effect of magnesium. An effective dose of calcium and magnesium to maintain healthy heart is crucial. Therefore, the purpose of the present study was to investigate a suitable combined dose of dietary Magnesium and Calcium that would bring the compatible effect to prevent atherosclerosis in high fat diet fed Wister Albino rats.

\section{Materials and Methods}

\section{Experimental animals}

The present study was conducted on 68 male Wister albino rats weighing between $110 \mathrm{gm}$ and $120 \mathrm{gm}$. The rats were purchased from Pharmacy Department of Jahangirnagar University. The animals were sorted into 17 groups (Table 1) where each group contained 4 rats. They were kept in separate polypropylene cages (4 rats in each cage) that were accommodated in a room maintained at controlled temperature $\left(25 \pm 2{ }^{\circ} \mathrm{C}\right.$ ), humidity and illumination conditions (a $12 \mathrm{~h}$ lightdark cycle) with free access to water and diet ad libitum for twelve weeks. All animals were acclimatized for one week prior to the experiments. All tests and surgery were performed under isoflurane ( $5 \%$ in $100 \%$ oxygen) anesthesia, and maximum efforts were made to minimize suffering. Animal care was based on principles and guidelines approved by the Guide for the Care and Use of Laboratory Animals (NIH publication No: 85-23, revised in 1985). The experimental procedures were approved by the Biomedical Research Center, University of Dhaka, Bangladesh.

Table 1: Animal grouping based on treatment received during 12 weeks of experiment.

\begin{tabular}{|c|c|}
\hline Groups & Treatment \\
\hline Group I & Non atherosclerotic control rats were fed normal diet daily for 84 days (Normal control). \\
\hline Group II & Model of atherosclerosis control rats were fed High-Fat Diet (HFD) daily for 84 days (Atherogenic control). \\
\hline Group III & Model of atherosclerosis rats were fed HFD + MgC03 200mg daily for 84 days. \\
\hline Group IV & Model of atherosclerosis rats were fed HFD + MgCO3 400mg daily for 84 days. \\
\hline Group V & Model of atherosclerosis rats were fed HFD + MgCO3 600mg daily for 84 days. \\
\hline Group VI & Model of atherosclerosis rats were fed HFD + CaCO3 500mg daily for 84 days. \\
\hline Group VII & Model of atherosclerosis rats were fed HFD + CaCO3 1000mg daily for 84 days. \\
\hline Group VIII & Model of atherosclerosis rats were fed HFD + CaCO3 1500mg daily for 84 days. \\
\hline Group IX & Model of atherosclerosis rats were fed HFD + Ca 1000 mg + Mg 400 mg daily for 84 days. \\
\hline Group X & Model of atherosclerosis rats were fed HFD + Ca 500 mg + Mg 400 mg daily for 84 days. \\
\hline Group XI & Model of atherosclerosis rats were fed HFD + Ca 1500 mg + Mg 400 mg daily for 84 days. \\
\hline Group XII & Model of atherosclerosis rats were fed HFD + Ca $1000 \mathrm{mg}+\mathrm{Mg} 200 \mathrm{mg}$ daily for 84 days. \\
\hline
\end{tabular}




\section{Open Access Journal of Toxicology}

\begin{tabular}{|c|c|}
\hline Group XIII & Model of atherosclerosis rats were fed HFD + Ca $500 \mathrm{mg}+\mathrm{Mg} 200 \mathrm{mg}$ daily for 84 days. \\
\hline Group XIV & Model of atherosclerosis rats were fed HFD + Ca $1500 \mathrm{mg}+\mathrm{Mg} 200 \mathrm{mg}$ daily for 84 days. \\
\hline Group XV & Model of atherosclerosis rats were fed HFD + Ca $1000 \mathrm{mg}+\mathrm{Mg} 600 \mathrm{mg}$ daily for 84 days. \\
\hline Group XVI & Model of atherosclerosis rats were fed HFD + Ca $500 \mathrm{mg}+\mathrm{Mg} 600 \mathrm{mg}$ daily for 84 days. \\
\hline Group XVII & Model of atherosclerosis rats were fed HFD + Ca $1500 \mathrm{mg}+\mathrm{Mg} 600 \mathrm{mg}$ daily for 84 days. \\
\hline
\end{tabular}

Conversion of human to animal dose for $\mathrm{MgCO}_{3}$ and $\mathrm{CaCO}_{3}$ salts have been done by using the following equation [35]: $\mathrm{HED}$ (mg/kg) = Animal does $(\mathrm{mg} / \mathrm{kg}) \times$ Animal $\mathrm{Km} /$ Human $\mathrm{Km}$

\section{Chemicals and nutritional supplements}

Magnesium carbonate and calcium carbonate salts were obtained from Eskayf Bangladesh Limited. Cholesterol was obtained from Sigma Aldrich Chemicals, Germany. Nutritional supplements including casein and cellulose were obtained from Merck India. Corn starch and soybean oil were collected from the local market (Unilever food, Bangladesh). All other minerals and vitamins for animal diet were obtained from Merck (Darmstadt, Germany) and were of analytical grade.

\section{Diet}

The importance of nutrient composition has been markedly related to the incidence of cardiovascular disease. Consumption of high-saturated fat diet is known to be associated with high risk of diabetes and cardiovascular disease [28,29]. A great number of animal models have been used to induce atherosclerosis and to test possible treatments for lowering circulating cholesterol level by feeding high saturated fat diet $[30,31]$. Such diet has proved to provoke hyperlipidemy in laboratory animals [32]. The present study followed a High-Fat Diet (HFD) composition that was previously established in 2005 by Matos SL et al. [33] in this diet the animals received $25 \%$ soybean oil, $1.0 \%$ cholesterol and $13 \%$ fiber with the total calories of $4538.4 \mathrm{Kcal} / \mathrm{Kg}$ (Table 2). In order to develop atherosclerosis, animals were fed highfat diet for 12 weeks. Diets were freshly prepared each day as pellets and the ingredients were separately stored at $4^{\circ} \mathrm{C}$. Around $15 \mathrm{~g}$ of dry food pellets were consumed by individual rat each day. Initial and final (after 12 weeks) body weight of rats in each group was assessed. The normal diet consisted of standard laboratory animal feed purchased from Pharmacy Department of Jahangirnagar University (Table 2).

Table 2: Composition of high-fat diet ( $\mathrm{g} / 1000 \mathrm{~g}$ of diet) as per Matos SL et al. [33].

\begin{tabular}{|c|c|}
\hline Ingredients & g/Kg \\
\hline Casein & 120 \\
\hline Corn starch & 429.6 \\
\hline Soybean oil & 250 \\
\hline Cholesterol & 10 \\
\hline Choline & 0.4 \\
\hline Salt mixture* & 50 \\
\hline Vitamin mixture** & 10 \\
\hline Cellulose & 130 \\
\hline Total calories (Kcal) & 4538.4 \\
\hline
\end{tabular}

Composition of salt mixture* $\left(\mathrm{g} / \mathrm{Kg}\right.$ of mixture): $\mathrm{NaCl}-139.3 / \mathrm{KI}-0.79 / \mathrm{MnSO}_{2} \mathrm{H}_{2} \mathrm{O}-4.01 / \mathrm{FeSO}_{4} .7 \mathrm{H}_{2} \mathrm{O}-27.0 / \mathrm{ZnSO}_{4} .7 \mathrm{H}_{2} \mathrm{O}-0.548 /$ $\mathrm{CuSO}_{4} \cdot 5 \mathrm{H}_{2} \mathrm{O}-0.477 / \mathrm{CoCl}_{2} \cdot 6 \mathrm{H}_{2} \mathrm{O}-0.023 / \mathrm{KH}_{2} \mathrm{PO}_{4}-389.0 / \mathrm{Mg}$ and $\mathrm{Ca}$ salts were given as per dose to each treatment group. Composition of vitamin mixture ${ }^{* *}$ (g/Kg of mixture): Retinol acetate - 2,000,000IU / Cholecalciferol - 200,000IU / P-aminobenzoic acid - $10.00 / \mathrm{I}$-Inositol - $10.00 /$ Niacin - 4.00 / Calcium pantotenate - 4.00 / Riboflavin - 0.80/ Tiamine HCL - 0.50 / Piridoxine HCL - 0.50 / Folic acid- 0.20 / Biotin - 0.04 / Vitamin B12 - 0.003 / Choline - 200.0 / $\alpha$-Tocopherol - 10,000IU/ Sucrose qsp 1000.

\section{Dose selection for $\mathrm{Ca}$ and $\mathrm{Mg}$ salts}

In our present study, we selected three separate doses of magnesium carbonate $(200 \mathrm{mg}, 400 \mathrm{mg}$ and $600 \mathrm{mg}$ of body weight) and calcium carbonate $(500 \mathrm{mg}, 1000 \mathrm{mg}$ and $1500 \mathrm{mg}$ of body weight) salts. According to National Institutes of Health (NIH, 2016) the daily requirement of magnesium and calcium by our body are $400 \mathrm{mg}$ and $1000 \mathrm{mg}$ of body weight respectively. Considering the normal dose, a lower and a higher dose of each of the salts have been selected to investigate their effects on reducing the risk of atherosclerosis. Earlier studies have been conducted using various doses (considering low, medium and higher) of dietary magnesium and calcium salts [18,27,34].
In our present investigation, the salts $\left(\mathrm{MgCO}_{3}\right.$ and $\left.\mathrm{CaCO}_{3}\right)$ of different doses (single and in combinations) were administered to the animals through diet (HFD) for 12 weeks (84 days). Based on the treatment with salts and diet, the experimental animals were divided into the following groups (Table 1).

Here, HED means human equivalent dose and Km means the correction factor which is estimated by dividing the average body weight $(\mathrm{kg})$ of species to its body surface area $\left(\mathrm{m}^{2}\right)$ [35]. For instance, the average human body weight is considered to be $60 \mathrm{~kg}$, and the body surface area is $1.62 \mathrm{~m}^{2}$, therefore, the $\mathrm{Km}$ factor for human is 37 [35]. 


\section{Evaluation of atherosclerosis}

\section{Determination of systolic blood pressure}

After 12 weeks of study, the systolic blood pressure of conscious rats from all groups was measured in a 300C environment by BP Monitor (Mk-1030, Mouromachi Kikaj Co. Ltd) at the Phytochemical Laboratory of Dhaka University. Systolic blood pressure was recorded by tail-cuff method and the values were the averages of five consecutive measurements for each rat from all groups [36].

\section{Blood sample collection}

After 84 days, all animals were fasted overnight for 12 hours before collection of blood. For this purpose, animals were sacrificed under sufficient illumination and general anesthetic condition. $2 \mathrm{ml}$ of blood with a $3 \mathrm{ml}$ syringe was collected from each rat by retro orbital puncture. The serum was obtained by centrifugation at $5000 \mathrm{rpm}$ for 5 minutes and stored at $-80^{\circ} \mathrm{C}$ until analysis.

\section{Biochemical determinations}

The serum samples were used to determine biochemical parameters involving Total Cholesterol (TC), Triglyceride (TG) and High-Density Lipoprotein Cholesterol (HDL-C). Total cholesterol was determined using the method as described by Roeschlau et al. [37] and an enzymatic method described by Tietz [38] was adopted in the estimation of triglycerides [38]. Both TC and TG were measured by taking the absorbance of the sample (Asample) and standard (Astandard) against the reagent blank within 60 minutes at 500nm wavelength. Determination of HDL was performed by using the method described by Burstein et al. [39] while the LDL-C was estimated according to the following formula; LDL-C = TC - HDL-C - TG/5 [40]. The measurement of HDL involved combination of phosphotungstate precipitation and enzymatic method. The precipitation of phosphotungstate was done by centrifugation at 4000rpm for 10 minutes and the supernatant was then carefully collected. For the enzymatic

Table 3: Changes of body weight of rats.

\begin{tabular}{|c|c|c|c|c|}
\hline \multirow[b]{2}{*}{ Group } & \multicolumn{4}{|c|}{ Body Weight (g) } \\
\hline & Initial Body Weight (g) & Final Body Weight (g) & $\begin{array}{c}\text { Change in Body Weight } \\
\text { (g) }\end{array}$ & $\begin{array}{c}\text { Change in Body Weight } \\
(\%)\end{array}$ \\
\hline I & $106 \pm 2.3$ & $140 \pm 5.3$ & 34 & 32.08 \\
\hline II & $108 \pm 2.6$ & $225 \pm 3.5$ & 117 & 108.33 \\
\hline III & $108 \pm 2.6$ & $185 \pm 4.4$ & 77 & 71.29 \\
\hline IV & $109 \pm 2.1$ & $195 \pm 2.6$ & 86 & 78.89 \\
\hline $\mathrm{V}$ & $109 \pm 3.5$ & $209 \pm 4.4$ & 100 & 91.74 \\
\hline VI & $110 \pm 3.2$ & $215 \pm 3.1$ & 105 & 95.45 \\
\hline VII & $111 \pm 3.2$ & $210 \pm 3.8$ & 99 & 89.19 \\
\hline VIII & $113 \pm 2.9$ & $210 \pm 5.5$ & 97 & 85.84 \\
\hline IX & $106 \pm 2.9$ & $200 \pm 3.8$ & 94 & 88.68 \\
\hline $\mathrm{X}$ & $115 \pm 5.2$ & $220 \pm 4.9$ & 105 & 91.3 \\
\hline XI & $115 \pm 3.2$ & $210 \pm 4.4$ & 95 & 82.61 \\
\hline
\end{tabular}

method, the absorbance of the standard and sample was measured at 500nm against the blank.

\section{Histopathology}

The progression of atherosclerotic plaque appears to be related to the amount of lipids that accumulate within the artery walls [41-43]. To evaluate the incident of atherosclerosis in animal models histology of organs were examined. Sections of aorta, kidney (tubular lumnens, mainly in the zona intermedia) and liver were fixed in freshly prepared $10 \%$ neutral buffered formalin at $4{ }^{\circ} \mathrm{C}$ for microscopic examinations. Tissue specimens were processed for paraffin embedding tissue sections $(5 \mu \mathrm{m}$ thick) prior to histopathological evaluation which was done in Exim Bank Hospital, Department of histopathology, Dhaka, Bangladesh.

\section{Statistical analysis}

All data generated from the present study were subjected to statistical analysis using one way ANOVA followed by Dunnett's test and presented in table and bar charts. Values at $\mathrm{p}<0.05$ deemed statistically significant.

\section{Results}

\section{Changes of body weight}

The experimental observation of changes in body weight of rats was made for 12 weeks. Significant difference in body weight was observed between rats fed with standard diet (controlled diet) and high-fat diet (HFD). As shown in Table 3, the initial body weight showed no difference in control (Group I), HFD group (Group II) as well as all HFD fed treatment groups (Group III - Group XVII), that was between $100 \mathrm{~g}$ and $120 \mathrm{~g}$. However, the final body weight (after 12 weeks) significantly increased in all groups as compared with initial weight. Animals fed controlled diet showed minimum increase in body weight (about 34g) while rats of other groups gained more than $80 \mathrm{~g}$ body weight than the initial weight. Maximum rise in percentage (108.33\%) of body weight was observed in rats fed HFD (Group II) (Table 3). 


\section{Open Access Journal of Toxicology}

\begin{tabular}{|c|c|c|c|c|}
\hline XII & $121 \pm 2.3$ & $216 \pm 3.2$ & 95 & 78.51 \\
\hline XIII & $120 \pm 2.6$ & $212 \pm 3.8$ & 92 & 76.67 \\
\hline XIV & $120 \pm 4.0$ & $220 \pm 3.5$ & 95 & 83.33 \\
\hline XV & $110 \pm 4.6$ & $205 \pm 2.6$ & 83 & 66.36 \\
\hline XVI & $121 \pm 2.1$ & $204 \pm 3.5$ & 110 & 100 \\
\hline XVII & $110 \pm 4.9$ & $220 \pm 2.3$ & 95 \\
\hline
\end{tabular}

The values of initial (week 0 ) and final (week 12) body weight of all groups of animals are expressed in Mean \pm SEM $(n=4)$. The changes in body weight is expressed in percentage. Group I = normal control, Group II = HFD control/atherogenic control, Group III = HFD $+\mathrm{MgCO}_{3} 200 \mathrm{mg}$ Group IV = HFD + MgCO 400mg, Group V = HFD + MgCO 600mg, Group VI = HFD + $\mathrm{CaCO}_{3}$ 500mg, Group VII $=\mathrm{HFD}+\mathrm{CaCO}_{3} 1000 \mathrm{mg}$ Group VIII = HFD $+\mathrm{CaCO}_{3} 1500 \mathrm{mg}$, Group IX = HFD + $\mathrm{Ca}^{2+} 1000 \mathrm{mg}+\mathrm{Mg} 400 \mathrm{mg}$, Group X = HFD + Ca ${ }^{2+} 500 \mathrm{mg}+\mathrm{Mg} 400 \mathrm{mg}$, Group XI $=\mathrm{HFD}+\mathrm{Ca}^{2+} 1500 \mathrm{mg}+\mathrm{Mg} 400 \mathrm{mg}$, Group XII = HFD + Ca ${ }^{2+} 1000 \mathrm{mg}+\mathrm{Mg} 200 \mathrm{mg}$, Group XIII = HFD + Ca ${ }^{2+} 500 \mathrm{mg}+\mathrm{Mg}_{200 \mathrm{mg}}, \mathrm{Group}$ XIV = HFD + Ca 1500mg + Mg 200 mg, Group XV = HFD + Ca1000 m +Mg 600 mg, Group XVI = HFD +Ca 500mg + Mg 600mg, Group XVII $=\mathrm{HFD}+\mathrm{Ca} 1500 \mathrm{mg}+\mathrm{Mg} 600 \mathrm{mg}$.

\section{Changes of systolic blood pressure}

After 12 weeks of study the mean systolic blood pressure was found to be significantly higher $(\mathrm{P}<0.01)$ in animals fed HFD (Group II; $188 \pm 3.5 \mathrm{mmHg}$ ) when compared to the mean systolic pressure of Group I animals (control group) that was found to be close to normal $(115 \pm 2.6 \mathrm{mmHg})$ as given in Table 4 . Similar observation was seen from Group III to Group VIII (mean SPB was found to be between $100 \mathrm{mmHg}$ and $130 \mathrm{mmHg}$ ) when compared to Group II (Table 4).

Table 4: Changes of Systolic blood pressure of rats after 12 week of the study period.

\begin{tabular}{|c|c|}
\hline Groups & $\begin{array}{c}\text { Mean Systolic Blood Pressure } \\
\text { (mmHg) }\end{array}$ \\
\hline Group I & $115 \pm 2.6^{* *}$ \\
\hline Group II & $188 \pm 3.5$ \\
\hline Group III & $125 \pm 5.1^{* *}$ \\
\hline Group IV & $120 \pm 5.5^{* *}$ \\
\hline Group V & $112 \pm 7.0^{* *}$ \\
\hline Group VI & $130 \pm 1.5^{* *}$ \\
\hline Group VII & $100 \pm 4.0^{* *}$ \\
\hline Group VIII & $114 \pm 4.6^{* *}$ \\
\hline
\end{tabular}

Data has been presented in Mean \pm SEM $(n=4)$. $\left(^{*}\right)$ indicates statistically significant difference from high fat diet fed rats $(G r o u p ~ I I)$ using ANOVA, followed by Dunnett's multiple comparison test $\left.{ }^{*} \mathrm{P}<0.01\right)$. Group I = normal control, Group II = HFD control/atherogenic control, Group III = HFD + $\mathrm{MgCO}_{3} 200 \mathrm{mg}$, Group IV = HFD + $\mathrm{MgCO}_{3} 400 \mathrm{mg}$, Group V = HFD + $\mathrm{MgCO}_{3} 600 \mathrm{mg}$, Group VI = HFD + CaCO $500 \mathrm{mg}, \mathrm{Group}$ $\mathrm{VII}=\mathrm{HFD}+\mathrm{CaCO}_{3} 1000 \mathrm{mg}, \mathrm{Group} \mathrm{VIII}=\mathrm{HFD}+\mathrm{CaCO}_{3} 1500 \mathrm{mg}$.

Table 5: Changes of Systolic blood pressure of rats after 12 week of the study period.

\begin{tabular}{|c|c|}
\hline Groups & $\begin{array}{c}\text { Mean Systolic Blood Pressure } \\
(\mathbf{m m H})\end{array}$ \\
\hline Group III & $125 \pm 5.1$ \\
\hline Group IX & $145 \pm 6.2^{n}$ \\
\hline Group X & $147 \pm 5.9^{n}$ \\
\hline Group XI & $146 \pm 3.8^{n}$ \\
\hline Group XII & $132 \pm 8.4^{n}$ \\
\hline Group XIII & $120 \pm 4.4^{n}$ \\
\hline Group XIV & $121 \pm 6.8^{n}$ \\
\hline Group XV & $110 \pm 4.0^{n}$ \\
\hline Group XVI & $102 \pm 10.6^{n}$ \\
\hline Group XVII & $120 \pm 7.0^{n}$ \\
\hline
\end{tabular}

Data has been presented in Mean \pm SEM $(n=4)$. $(\eta)$ indicates statistically no significant difference from rats fed with $200 \mathrm{mg}$ of $M g C O 3$ containing high fat diet (Group III) using ANOVA, followed by Dunnett's multiple comparison test $(\mathrm{P}>0.05)$. Group III $=\mathrm{HFD}^{2} \mathrm{MgCO}_{3} 200 \mathrm{mg}$, Group IX = HFD + $\mathrm{Ca}^{2+} 1000 \mathrm{mg}+\mathrm{Mg} 400 \mathrm{mg}$, Group X = HFD + $\mathrm{Ca}^{2+} 500 \mathrm{mg}+\mathrm{Mg} 400 \mathrm{mg}$, Group XI = HFD + Ca ${ }^{2+} 1500 \mathrm{mg}+\mathrm{Mg} 400 \mathrm{mg}$ Group XII = HFD + $\mathrm{Ca}^{2+} 1000 \mathrm{mg}+\mathrm{Mg} 200 \mathrm{mg}$, Group XIII $=\mathrm{HFD}+\mathrm{Ca}^{2+} 500 \mathrm{mg}+\mathrm{Mg} 200 \mathrm{mg}$, Group XIV = HFD + Ca $1500 \mathrm{mg}+\mathrm{Mg} 200$ $\mathrm{mg}$, Group XV = HFD + Ca1000 mg + Mg 600 mg, Group XVI = HFD + Ca 500mg + Mg 600mg, Group XVII = HFD + Ca 1500mg + Mg 600mg 


\section{Open Access Journal of Toxicology}

Table 6: Changes of Systolic blood pressure of rats after 12 week of the study period.

\begin{tabular}{|c|c|}
\hline Groups & Mean Systolic Blood Pressure (mmHg) \\
\hline Group IV & $120 \pm 5.5$ \\
\hline Group IX & $145 \pm 6.2^{\eta}$ \\
\hline Group X & $147 \pm 5.9^{\eta}$ \\
\hline Group XI & $146 \pm 3.8^{\eta}$ \\
\hline Group XII & $132 \pm 8.4^{\eta}$ \\
\hline Group XIII & $120 \pm 4.4^{\eta}$ \\
\hline Group XIV & $121 \pm 6.1^{\eta}$ \\
\hline Group XV & $110 \pm 4.0^{\eta}$ \\
\hline Group XVI & $102 \pm 10.6^{\eta}$ \\
\hline Group XVII & $120 \pm 7.0^{\eta}$ \\
\hline
\end{tabular}

Data has been presented in Mean \pm SEM $(n=4)$. $(\eta)$ indicates statistically no significant difference from rats fed with $400 \mathrm{mg}$ of $\mathrm{MgCO}$ containing high fat diet (Group IV) using ANOVA, followed by Dunnett's multiple comparison test ( $P>0.05)$. Group IV $=\mathrm{HFD}^{2} \mathrm{MgCO}_{3} 400 \mathrm{mg}$, Group IX = HFD + $\mathrm{Ca}^{2+} 1000 \mathrm{mg}+\mathrm{Mg} 400 \mathrm{mg}$, Group X = HFD + Ca ${ }^{2+} 500 \mathrm{mg}+\mathrm{Mg} 400 \mathrm{mg}$, Group XI $=\mathrm{HFD}+\mathrm{Ca}^{2+} 1500 \mathrm{mg}+\mathrm{Mg} 400 \mathrm{mg}$, Group XII = HFD + $\mathrm{Ca}^{2+} 1000 \mathrm{mg}+\mathrm{Mg} 200 \mathrm{mg}$, Group XIII = HFD + $\mathrm{Ca}^{2+} 500 \mathrm{mg}+\mathrm{Mg} 200 \mathrm{mg}$, Group XIV = HFD + Ca $1500 \mathrm{mg}+\mathrm{Mg} 200 \mathrm{mg}$, Group XV = HFD + Ca 1000 mg + Mg 600 mg, Group XVI = HFD + Ca 500mg + Mg 600mg, Group XVII = HFD + Ca 1500mg + Mg 600mg.

Table 7: Changes of Systolic blood pressure of rats after 12 week of the study period.

\begin{tabular}{|c|c|}
\hline Groups & Mean Systolic Blood Pressure (mmHg) \\
\hline Group V & $112 \pm 7.0$ \\
\hline Group IX & $145 \pm 6.2^{*}$ \\
\hline Group X & $147 \pm 5.9^{* *}$ \\
\hline Group XI & $146 \pm 3.8^{*}$ \\
\hline Group XII & $132 \pm 8.4 \eta$ \\
\hline Group XIII & $120 \pm 4.4 \eta$ \\
\hline Group XIV & $121 \pm 6.1 \eta$ \\
\hline Group XV & $110 \pm 4.0 \eta$ \\
\hline Group XVI & $102 \pm 10.6 \eta$ \\
\hline Group XVII & $120 \pm 7.0 \eta$ \\
\hline
\end{tabular}

Data has been presented in Mean \pm SEM $(n=4)$. $\left(^{*}\right)$ indicates statistically significant difference from rats fed with $600 \mathrm{mg}$ of $\mathrm{MgCO}_{3}$ containing high fat diet (Group V) using ANOVA, followed by Dunnett's multiple comparison test $\left({ }^{*} P<0.05,{ }^{* *} P<0.01\right)$. ( $\eta$ ) indicates statistically no significant difference from rats fed with $600 \mathrm{mg}$ of $\mathrm{MgCO}_{3}$ containing high fat diet (Group V) using ANOVA, followed by Dunnett's multiple comparison test $(\mathrm{P}>0.05)$. Group V = HFD + $\mathrm{MgCO}_{3} 600 \mathrm{mg}$, Group IX = HFD + $\mathrm{Ca}^{2+} 1000 \mathrm{mg}+\mathrm{Mg} 400 \mathrm{mg}$, Group X = HFD + $\mathrm{Ca}^{2+} 500 \mathrm{mg}+\mathrm{Mg} 400 \mathrm{mg}, \mathrm{Group}$ $\mathrm{XI}=\mathrm{HFD}+\mathrm{Ca}^{2+} 1500 \mathrm{mg}+\mathrm{Mg} 400 \mathrm{mg}$, Group XII = HFD + $\mathrm{Ca}^{2+} 1000 \mathrm{mg}+\mathrm{Mg} 200 \mathrm{mg}$, Group XIII = HFD + Ca ${ }^{2+} 500 \mathrm{mg}+\mathrm{Mg}_{200} \mathrm{mg}, \mathrm{Group}$ XIV = HFD + Ca 1500mg + Mg 200 mg, Group XV = HFD + Ca 1000 mg +Mg 600 mg, Group XVI = HFD +Ca 500mg + Mg 600mg, Group XVII $=\mathrm{HFD}+\mathrm{Ca} 1500 \mathrm{mg}+\mathrm{Mg} 600 \mathrm{mg}$.

Experimental observation was made to compare mean systolic blood pressure of rats fed with different doses of dietary Magnesium (200, 400 and 600mg) provided in HFD versus rats fed with HFD containing combined doses of magnesium and calcium (Groups IX to XVII) using the one-way ANOVA followed by Dunnett's test as represented in Table 5-7. In Tables $5 \& 6$, the one-way ANOVA indicated no significant difference in mean SBP $(\mathrm{P}>0.05)$ between rats fed added magnesium in HFD $(200 \mathrm{mg}$ and $400 \mathrm{mg}$ ) and those fed combined doses of magnesium and calcium containing HFD (Groups IX to XVII). The effect of dietary regimens including Group V (HFD + Mg 600mg) versus Groups IX to XVII on the mean SBP of experimental animals has been shown in Table 7. Significant difference $(\mathrm{P}<0.05)$ in mean systolic blood pressure was found when compared Group V with that of Groups IX, X and XI $\left(145 \pm 6.2^{*}, 147 \pm 5.9^{* *} \& 146 \pm 3.8^{*}\right)$ where Group X indicated very significant $(\mathrm{P}<0.01)$ result in rising the mean SBP after 12 weeks of experiment. No significant differences $(\mathrm{P}>0.05)$ in mean SBP were found to be evident when compared Group V with the rest of the Groups presented in Table 7.

\section{Changes of lipid profile}

The effects of HFD and dietary magnesium and calcium in high fat diet on mean values of serum lipid profile have been shown in Figure 1 where one-way ANOVA followed by Dunnett's test has been considered to compare results of HFD group (Group II) with normal control (Group I) and treatment groups (Groups III to VIII). There were very significant differences $(\mathrm{P}<0.01)$ on mean serum cholesterol, triglyceride and LDL levels found between normal control group $(80 \pm 5.86 \mathrm{mg} / \mathrm{dl}$, $47 \pm 4.93 \mathrm{mg} / \mathrm{dl}, 40 \pm 4.62 \mathrm{mg} / \mathrm{dl})$ and HFD group $(175 \pm 7.81 \mathrm{mg} /$ 
dl, $96 \pm 5.29 \mathrm{mg} / \mathrm{dl}, 140 \pm 4.36 \mathrm{mg} / \mathrm{dl})$ after 12 weeks of study period. Similar results were seen $(\mathrm{P}<0.01)$ between HFD and all other treatment groups (added calcium and magnesium salts in HFD) in case of serum cholesterol and LDL levels. No significant differences $(\mathrm{P}>0.05)$ found after week 12 between HFD group and groups fed with $500 \mathrm{mg}$ and $1000 \mathrm{mg}$ calcium salt (Groups VI \& VII) and $200 \mathrm{mg}$ and $400 \mathrm{mg}$ magnesium salts (Groups III \& IV) in high-fat diet regarding serum triglyceride level. However, significant differences $(\mathrm{P}<0.05)$ in serum triglyceride level were found in case of groups fed with $1500 \mathrm{mg}$ calcium salt (Group
VIII) and 600mg magnesium salt (Group V) in high fat diet when compared with HFD group. Among all the parameters of lipid profile, serum HDL level showed no significant changes $(\mathrm{P}>0.05)$ between HFD and normal control as well as all the other treatment groups (Group III, IV, V, VI and VIII) except for the group that consumed $1000 \mathrm{mg}$ of calcium salt in high fat diet (Group VII) exhibited much higher HDL level after 12 weeks of study period $(13 \pm 2.89 \mathrm{mg} / \mathrm{dl}$ vs $35 \pm 2.08 \mathrm{mg} / \mathrm{dl}, \mathrm{P}<0.01)$, as shown in Figure 1.

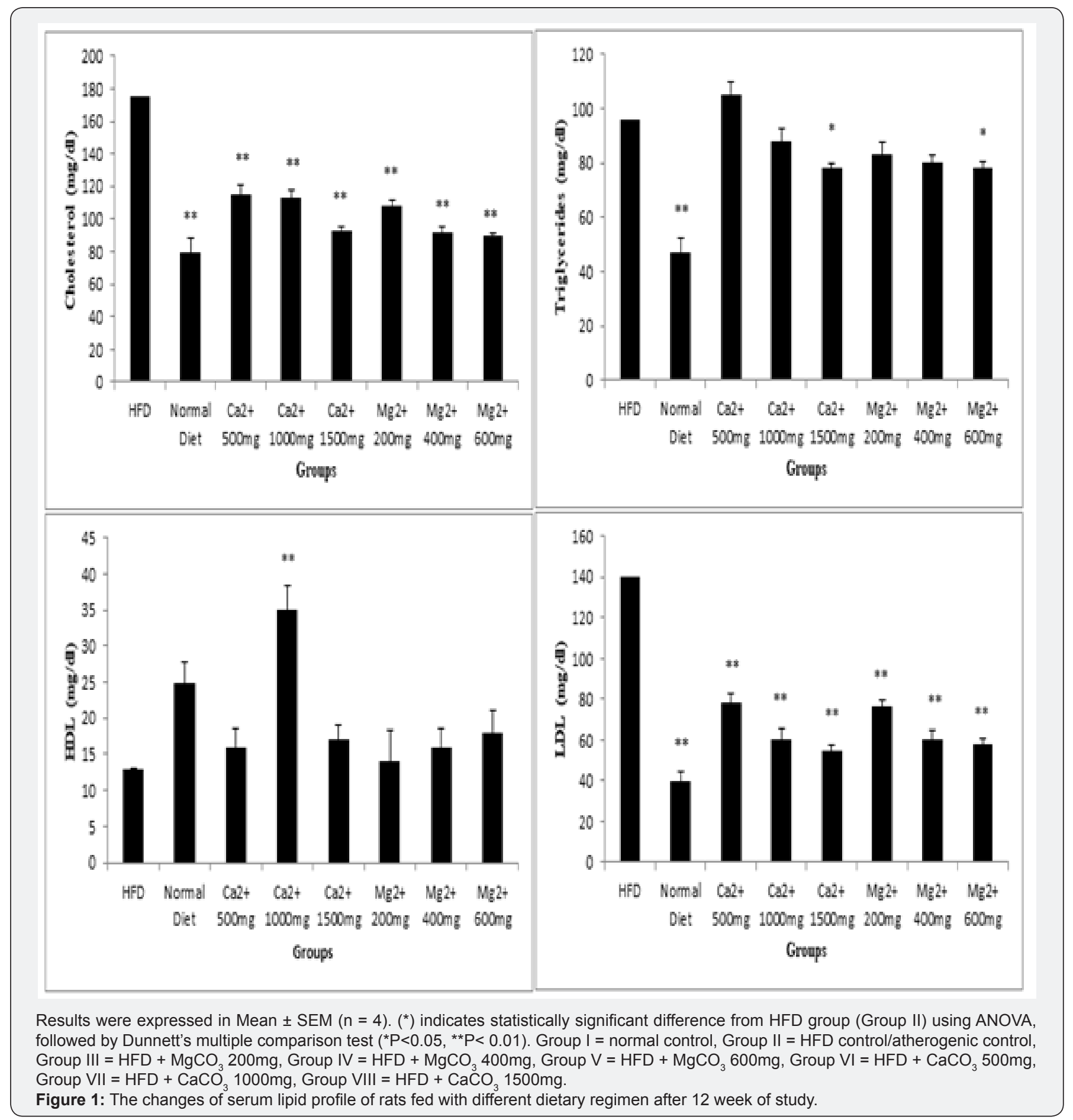


Influence of different doses of dietary magnesium $(200 \mathrm{mg}$, $400 \mathrm{mg}$ and $600 \mathrm{mg}$ respectively) in HFD (Groups III, IV and V) on serum lipid profile was compared with that of HFD containing combined doses of Magnesium and Calcium salts (Groups IX to XVII) using the one-way ANOVA followed by Dunnett's test as represented in the Figures 2-4. The results shown in Figure 2 indicates that serum cholesterol, triglyceride and LDL levels significantly rose the most in Group XII (HFD $+\mathrm{Ca}^{2+} 1000 \mathrm{mg}$ $+\mathrm{Mg} 200 \mathrm{mg}$ ) as compared with animals consumed $200 \mathrm{mg}$ of magnesium salt in HFD $(172 \pm 2.89 \mathrm{mg} / \mathrm{dl}, 98 \pm 4.04 \mathrm{mg} / \mathrm{dl}$ and $134 \pm 3.05 \mathrm{mg} / \mathrm{dl}$ vs $108 \pm 3.61 \mathrm{mg} / \mathrm{dl}, 83 \pm 2.89 \mathrm{mg} / \mathrm{dl}$ and $\left.77 \pm 4.93 \mathrm{mg} / \mathrm{dl} ;{ }^{*} \mathrm{P}<0.05-{ }^{* *} \mathrm{P}<0.01\right)$. On the other hand, Figure
2 evidently showed that serum cholesterol, triglyceride and LDL levels of animals of Groups XV and XVII significantly decreased the most than any other groups when compared with animals fed with $\mathrm{HFD}+\mathrm{MgCO}_{3} 200 \mathrm{mg}(80 \pm 5.51 \mathrm{mg} / \mathrm{dl}$ and $84 \pm 4.73 \mathrm{mg} /$ $\mathrm{dl}$ vs $108 \pm 3.61 \mathrm{mg} / \mathrm{dl}, \quad 62 \pm 5.19 \mathrm{mg} / \mathrm{dl}$ and $55 \pm 2.31 \mathrm{mg} /$ dl vs $83 \pm 2.89 \mathrm{mg} / \mathrm{dl}, 40 \pm 3.46 \mathrm{mg} / \mathrm{dl}$ and $40 \pm 1.73 \mathrm{mg} / \mathrm{dl}$ vs $\left.77 \pm 4.93 \mathrm{mg} / \mathrm{dl} ;{ }^{* *} \mathrm{P}<0.01\right)$. However, in the same figure (Figure 2) no significant differences $(\mathrm{P}>0.05)$ found in serum HDL levels between rats consumed diet containing HFD + MgCO3 200mg (Group III) and the rest of the treatment groups (Groups IX to XVII).

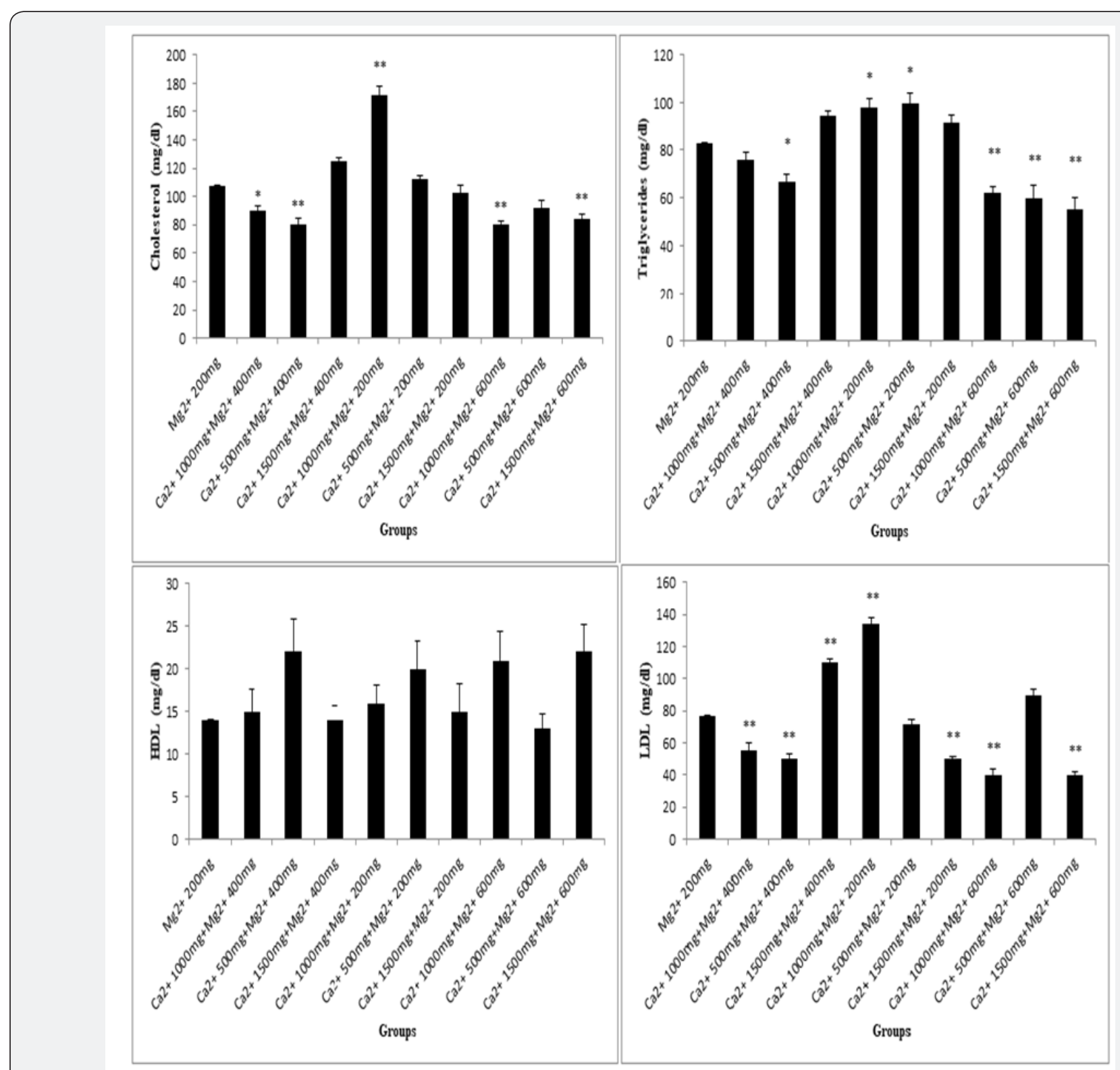

Results were expressed in in Mean \pm SEM $(n=4)$. $\left(^{*}\right)$ indicates statistically significant difference from Group III $\left(\mathrm{HFD}+\mathrm{MgCO}_{3}\right.$ $200 \mathrm{mg})$ using ANOVA, followed by Dunnett's multiple comparison test $\left({ }^{*} \mathrm{P}<0.05,{ }^{*} \mathrm{P}<0.01\right)$. Group IX $=\mathrm{HFD}+\mathrm{Ca} 2+1000 \mathrm{mg}+\mathrm{Mg}$ $400 \mathrm{mg}$, Group X = HFD + $\mathrm{Ca}^{2+} 500 \mathrm{mg}+\mathrm{Mg} 400 \mathrm{mg}$, Group XI $=\mathrm{HFD}+\mathrm{Ca}^{2+} 1500 \mathrm{mg}+\mathrm{Mg} 400 \mathrm{mg}$, Group XII $=\mathrm{HFD}+\mathrm{Ca}^{2+}$ $1000 \mathrm{mg}+\mathrm{Mg} 200 \mathrm{mg}$, Group XIII = HFD + $\mathrm{Ca}^{2+} 500 \mathrm{mg}+\mathrm{Mg} 200 \mathrm{mg}$, Group XIV = HFD + Ca 1500mg + Mg $200 \mathrm{mg}$, Group XV $=\mathrm{HFD}+\mathrm{Ca} 1000 \mathrm{mg}+\mathrm{Mg} 600 \mathrm{mg}$, Group XVI = HFD +Ca 500mg + Mg 600mg, Group XVII = HFD + Ca 1500mg + Mg 600mg. Figure 2: The changes of serum lipid profile of rats fed with different dietary regimen after 12 week of study. 
The Figures $3 \& 4$ represent comparison of results of Groups $\mathrm{IV}$ and $\mathrm{V}\left(\mathrm{HFD}+\mathrm{MgCO}_{3} 400 \mathrm{mg}\right.$ and $\left.\mathrm{HFD}+\mathrm{MgCO}_{3} 600 \mathrm{mg}\right)$ with the rest of the treatment groups (Groups IX to XVII) regarding changes of lipid profile in rats. These figures demonstrate that there was maximum significant difference in serum cholesterol, triglyceride and LDL levels in rats fed with added 400mg and $600 \mathrm{mg}$ of magnesium salts in HFD when compared with Group XII $\left(\mathrm{HFD}+\mathrm{Ca}^{2+} 1000 \mathrm{mg}+\mathrm{Mg} 200 \mathrm{mg}\right)(92 \pm 1.73 \mathrm{mg} / \mathrm{dl}, 80 \pm 2.65 \mathrm{mg} /$ $\mathrm{dl}, \quad 60 \pm 2.65 \mathrm{mg} / \mathrm{dl}$ and $90 \pm 3.79 \mathrm{mg} / \mathrm{dl}, \quad 78 \pm 4.04 \mathrm{mg} / \mathrm{dl}$, $58 \pm 3.46 \mathrm{mg} / \mathrm{dl}$ vs $172 \pm 2.89 \mathrm{mg} / \mathrm{dl}, 98 \pm 4.04 \mathrm{mg} / \mathrm{dl}, 134 \pm 3.05 \mathrm{mg} /$ $\mathrm{dl}$ and $172 \pm 2.89 \mathrm{mg} / \mathrm{dl}, 98 \pm 4.04 \mathrm{mg} / \mathrm{dl}, 134 \pm 3.05 \mathrm{mg} / \mathrm{dl}$; **P $<0.01$ ). Besides, serum triglyceride and LDL levels significantly decreased by the lowest value when compared between Groups IV and XVII, as well as between Groups V and XVII $(80 \pm 2.65 \mathrm{mg} /$ $\mathrm{dl}, \quad 60 \pm 2.65 \mathrm{mg} / \mathrm{dl}$ vs $55 \pm 2.31 \mathrm{mg} / \mathrm{dl}, \quad 40 \pm 1.73 \mathrm{mg} / \mathrm{dl}$ and $78 \pm 4.04 \mathrm{mg} / \mathrm{dl}, 58 \pm 3.46 \mathrm{mg} / \mathrm{dl}$ vs $55 \pm 2.31 \mathrm{mg} / \mathrm{dl}, 40 \pm 1.73 \mathrm{mg} / \mathrm{dl}$; $* * \mathrm{P}<0.01)$. Apparently, the results of Groups XII and XVII showed same values of (increased or/and decreased) serum cholesterol, triglyceride and LDL levels when compared with both Groups IV and V. However, no significant changes $(\mathrm{P}>0.05)$ seen in case of serum HDL level of animals of any of the treatment groups (Groups IX to XVII) as compared with animals of Groups IV and $\mathrm{V}$ (Figure 2).

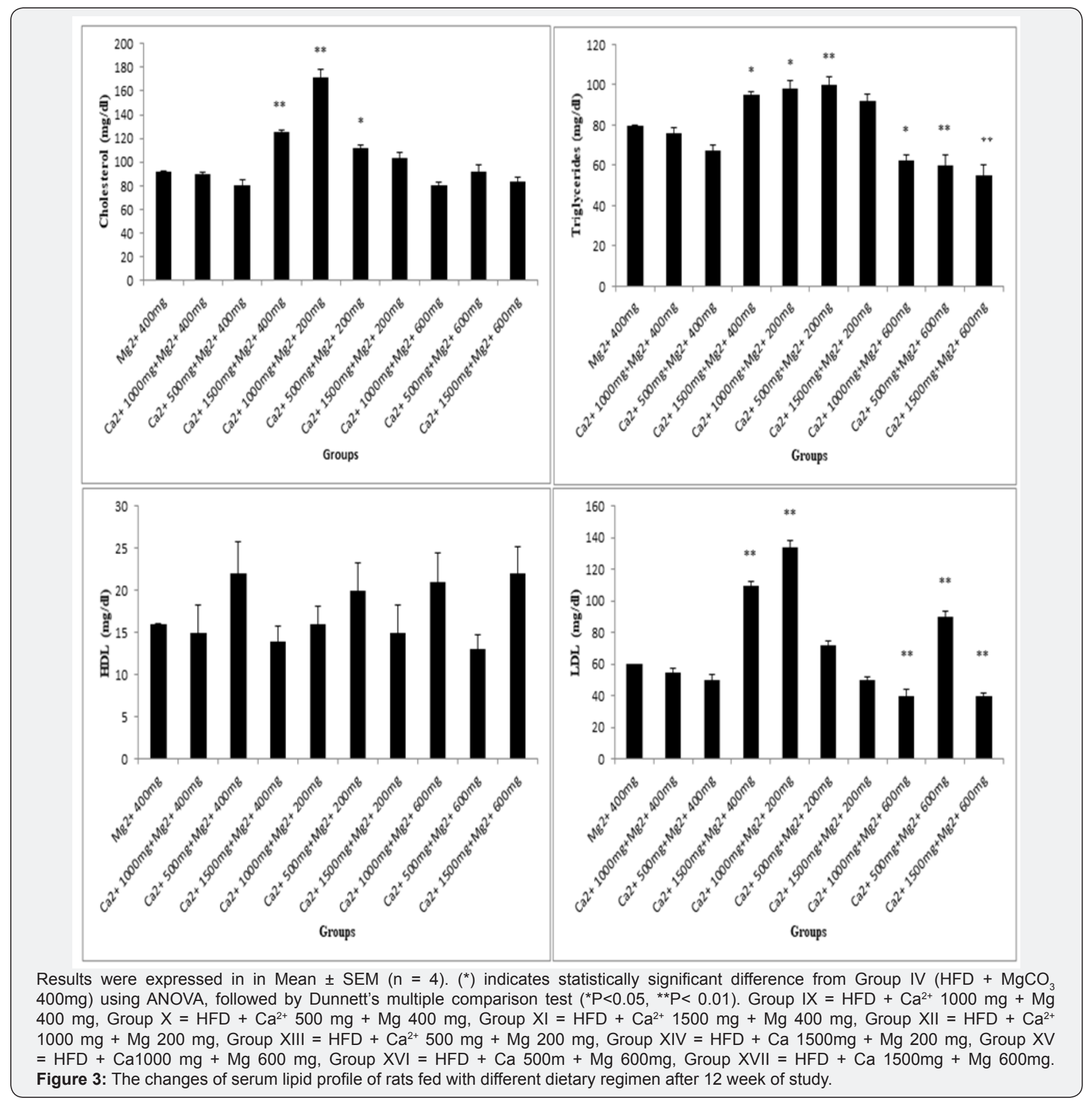




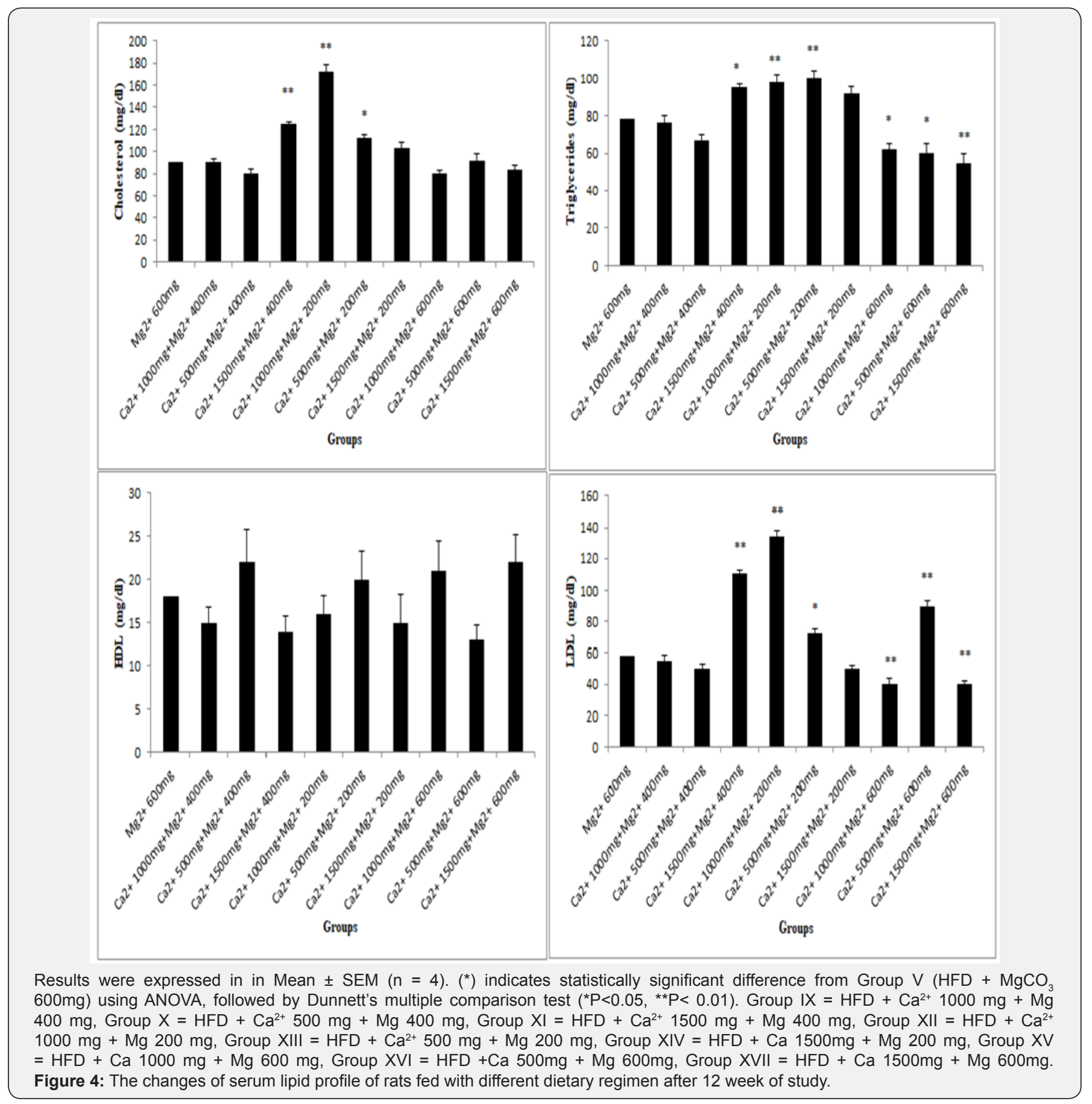

\section{Histopathological evaluation}

\section{Effect of Magnesium and Calcium salts containing high fat diet on histopathology of aorta, kidney and liver}

\section{Aorta}

In the Figure 5, normal control group (Group I; Figure $5 \mathrm{~A})$ demonstrated a much regular arrangement of cardiac myocytes showing vessels in the intima much prominently. Rats consumed HFD showed accumulation of fats via development of macrophage-derived foam cells (MFC) which indicated incidence of atherosclerosis (Figure 5B). Transition of cardiac monocytes into the lipid-laden macrophages called "foam cells" consisting of lipid droplets which results in atherosclerotic lesions [44]. A diverse morphological features in the aortic walls of experimental animals with different doses of Magnesium $(200 \mathrm{mg} / 400 \mathrm{mg} / 600 \mathrm{mg}$ ) and Calcium $(500 \mathrm{mg} / 1000 \mathrm{mg} / 1500 \mathrm{mg}$ ) salts in HFD was found via histological results (Figure 5C-5Q). High dose of calcium carbonate (1500mg) in HFD (Figure 5H) showed much destruction of cardiac myocytes and lymphocyte infiltration as compared with the histology of aorta of rats consumed high dose of magnesium carbonate (600mg) in HFD (Figure 5E) (Group VIII vs Group V; Figure 5H vs 5E). Considerable lipid deposition with formation of MFC and destruction of smooth muscle cells, 
intimal cells, endothelial cells, fibroblast-like cells (indicated in red and blue arrows, Figure 5I-5Q) was observed in sections of aorta of rats consumed different combination of magnesium and calcium salts in high fat diet (Group IX-Group XVII). This indicated development of progressive atherosclerotic lesions. However, Groups IX, XV and XVII showed fewer foam cells within the intima of the aortic wall with lesser destruction of endothelial cells as well as moderate to minimal degeneration of smooth muscle cells associated with low calcification when compared with other treatment groups including Groups X, XI, XII, XIII, XIV and XVI (Figure 5I, 50 \& 5Q vs 5J, 5K, 5L, 5M, 5N \& $5 \mathrm{P})$.

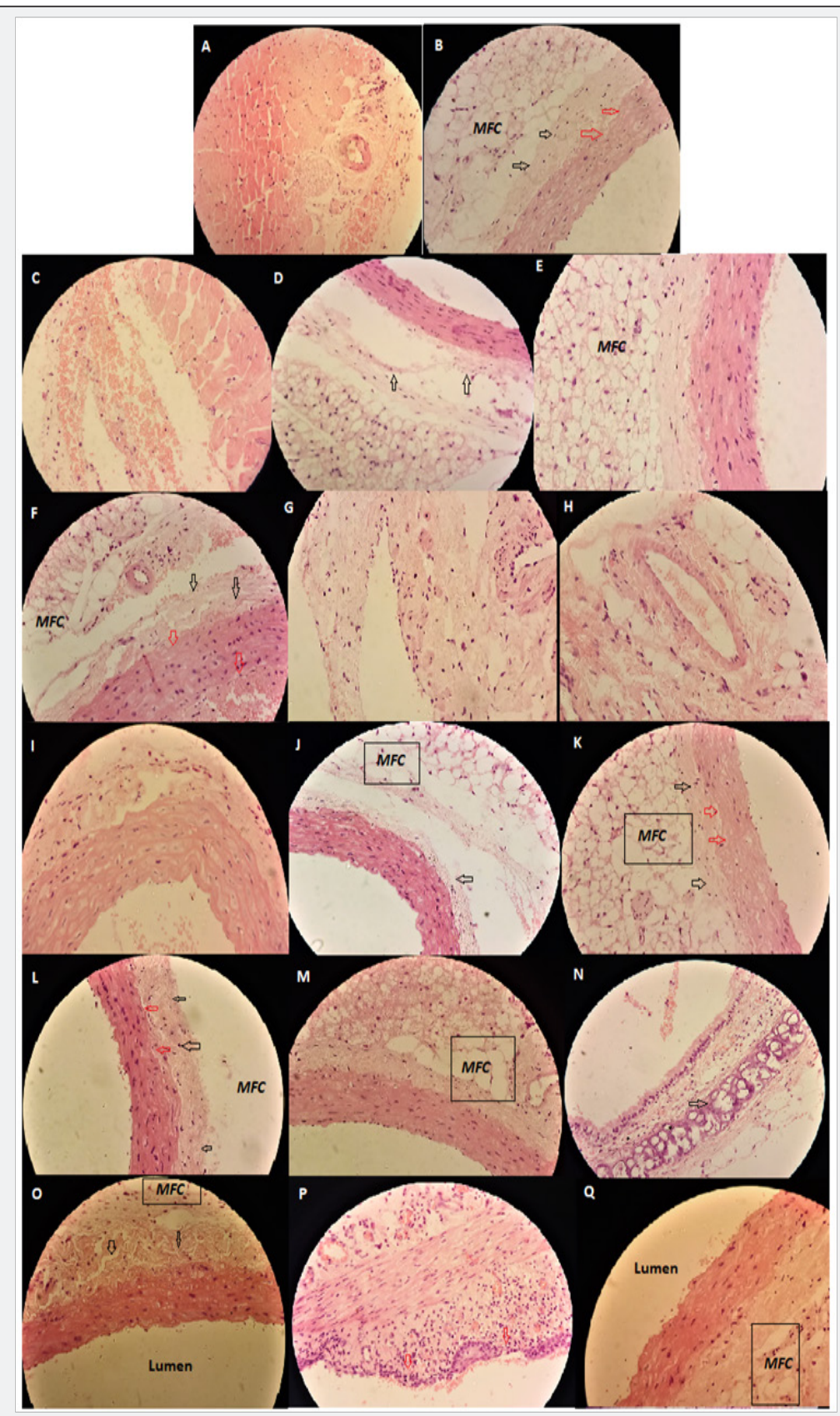

Rats consumed atherogenic diet developed macrophage-derived foam cells (MFC) with the destruction of smooth muscle cells (black arrow) as well as degeneration of endothelial cells around the lumen (red arrow) (B-Q).

(A) Group I = normal control, (B) Group II = HFD control/atherogenic control, (C) Group III = HFD + MgCO3 200mg, (D) Group IV = HFD + MgCO3 400mg, (E) Group V = HFD + MgCO3 600mg, (F) Group VI = HFD + CaCO3 500mg, (G) Group VII = HFD + CaCO3 1000mg, (H) Group VIII = HFD + CaCO3 1500mg, (I) Group IX = HFD + Ca2+ $1000 \mathrm{mg}+\mathrm{Mg} 400 \mathrm{mg}$, (J) Group X = HFD + Ca2+ $500 \mathrm{mg}+\mathrm{Mg} 400 \mathrm{mg}$, (K) Group XI = HFD + Ca2+ 1500 mg + Mg 400 mg, (L) Group XII = HFD + Ca2+ 1000 mg + Mg 200 mg, (M) Group XIII = HFD + Ca2+ 500 mg + Mg 200 mg, (N) Group XIV = HFD + Ca 1500mg + Mg 200 mg, (O) Group XV = HFD + Ca1000 mg + Mg 600 mg, (P) Group XVI = HFD +Ca 500mg + Mg 600mg, (Q) Group XVII = HFD + Ca 1500mg + Mg 600mg. Each group was assessed at 400X magnification, scale bar: $40 \mu \mathrm{m}$.

Figure 5: Effect of different dietary regimen (containing magnesium and calcium slats) on histological changes of the cross-section of aortas of rats after 12 week of study. 


\section{Kidney}

A considerable difference in the morphological features of kidney was found between rats with normal control and HFD in terms of accumulation of fat and damaged cells (Figure 6A \& 6B). The morphology of the outer portion of the medulla of kidney of normal group (Group I) showed regular arrangement of cells with minimum lipid deposition (Figure 6A). Consumption of high fat diet by animals resulted in abnormal histology of kidney associated with presence of extensive fat deposition around glomeruli and infiltration of red blood cells (Figure 6B). Morphological variation was observed in different combination of dietary magnesium and calcium salts with HFD. Consumption of high dietary magnesium salt $(600 \mathrm{mg})$ in high fat diet exhibited improved morphology of kidney (Figure 6E). On the other hand, much abnormal cellular morphology involving destructed glomeruli and infiltration of red blood cells was seen in case of rats consumed high dietary calcium salt $(1500 \mathrm{mg})$ in HFD (Figure 6H). The basis of renal lesion is similar to that of aortic lesion with respect to different combinations of magnesium and calcium salts in high-fat diet. The histology for the combined effect of magnesium carbonate and calcium carbonate in HFD of Groups IX, XV, XVI and XVII animals demonstrated smaller extent of fat deposition with moderately prominent glomeruli, collecting ducts, tubules and ascending and descending loops (Figure 6I, 60, 6P \& 6Q) as compared with other treatment groups (Groups X, XI, XII, XIII and XIV; Figure 6J, 6K, 6L, 6M \& $6 \mathrm{~N})$.

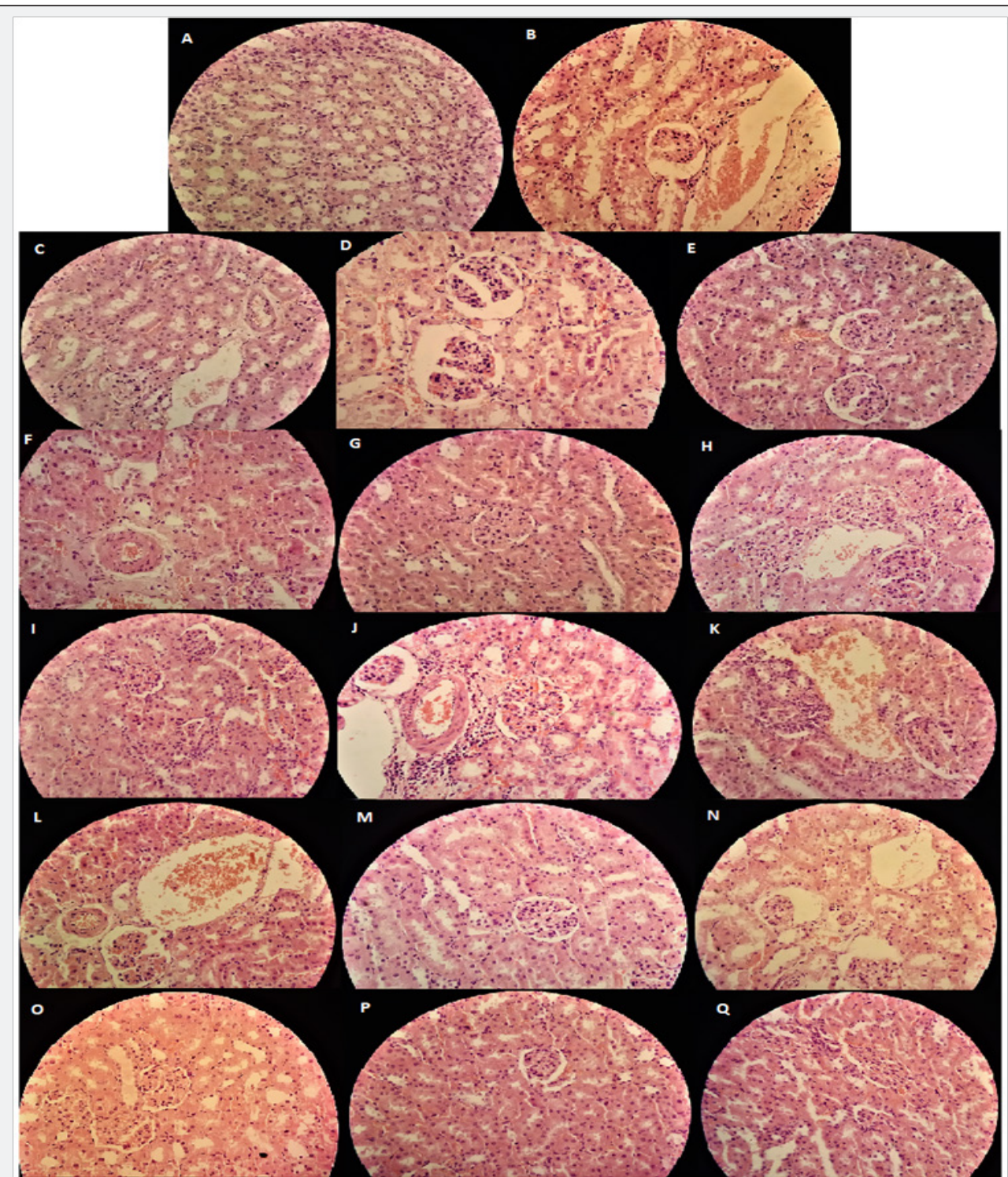

(A) Group I = normal control, (B) Group II = HFD control/atherogenic control, (C) Group III = HFD + $\mathrm{MgCO}_{3} 200 \mathrm{mg}$, (D) Group IV = HFD + $\mathrm{MgCO}_{3} 400 \mathrm{mg}$, (E) Group V = HFD + $\mathrm{MgCO}_{3} 600 \mathrm{mg}$, (F) Group VI = HFD + $\mathrm{CaCO}_{3} 500 \mathrm{mg}$, (G) Group VII = HFD $+\mathrm{CaCO}_{3} 1000 \mathrm{mg},(\mathrm{H})$ Group VIII = HFD $+\mathrm{CaCO}_{3} 1500 \mathrm{mg}$, (I) Group IX = HFD + Ca ${ }^{2+} 1000 \mathrm{mg}+\mathrm{Mg} 400 \mathrm{mg}$, (J) Group X = HFD + Ca ${ }^{2+} 500 \mathrm{mg}+\mathrm{Mg} 400 \mathrm{mg}$, (K) Group XI = HFD + $\mathrm{Ca}^{2+} 1500 \mathrm{mg}+\mathrm{Mg} 400 \mathrm{mg}$, (L) Group XII $=\mathrm{HFD}+\mathrm{Ca}^{2+} 1000 \mathrm{mg}+\mathrm{Mg} 200 \mathrm{mg}$, (M) Group XIII = HFD + Ca ${ }^{2+} 500 \mathrm{mg}+$ Mg 200 mg, (N)Group XIV = HFD + Ca 1500mg + Mg 200 mg, (O) Group XV = HFD + Ca 1000 mg +Mg 600 mg, (P) Group XVI = HFD +Ca $500 \mathrm{mg}+\mathrm{Mg} 600 \mathrm{mg},(\mathrm{Q})$ Group XVII = HFD + Ca $1500 \mathrm{mg}+\mathrm{Mg} 600 \mathrm{mg}$. Each group was assessed at 400X magnification, scale bar: $40 \mu \mathrm{m}$. Figure 6: Effect of different dietary regimen (containing magnesium and calcium slats) on histological changes of outer portion of the medulla of kidney of rats after 12 week of study. 


\section{Liver}

Liver tissue of atherogenic rats (Group II) showed extensive deposition of fat leading to abnormal arrangement of cells around the central vein resulting enlarged and thick walls of veins and capillaries along with cellular infiltration (Figure 7B). This indicated the development of microvesicular steatosis of the liver. The normal control group showed regular cellular arrangement around the central vein with no sign of infiltration of red blood cell (Figure 7A). The histopathological image of liver tissue of animals consumed high dose $(600 \mathrm{mg})$ of dietary magnesium in their high fat diet demonstrated better arrangement of hepatocytes around the central vein and least deposition of fat as compared to animals consumed higher dose $(1500 \mathrm{mg}$ ) of calcium slats in their HFD (Figure 7E vs 7H). However, morphological features of liver tissue of Groups IX, $\mathrm{XV}, \mathrm{XVI}$ and XVII animals remain nearly normal with minimum lipid deposition and cellular infiltration in the central vein while the rest of the treatment groups (Groups X, XI, XII, XIII and XIV) showed development of fibrosis in the degenerated hepatocytes along with extensive accumulation of fat (Figure 7I, 70, 7P \& 7Q vs 7J, 7K, 7L, 7M \& 7N).

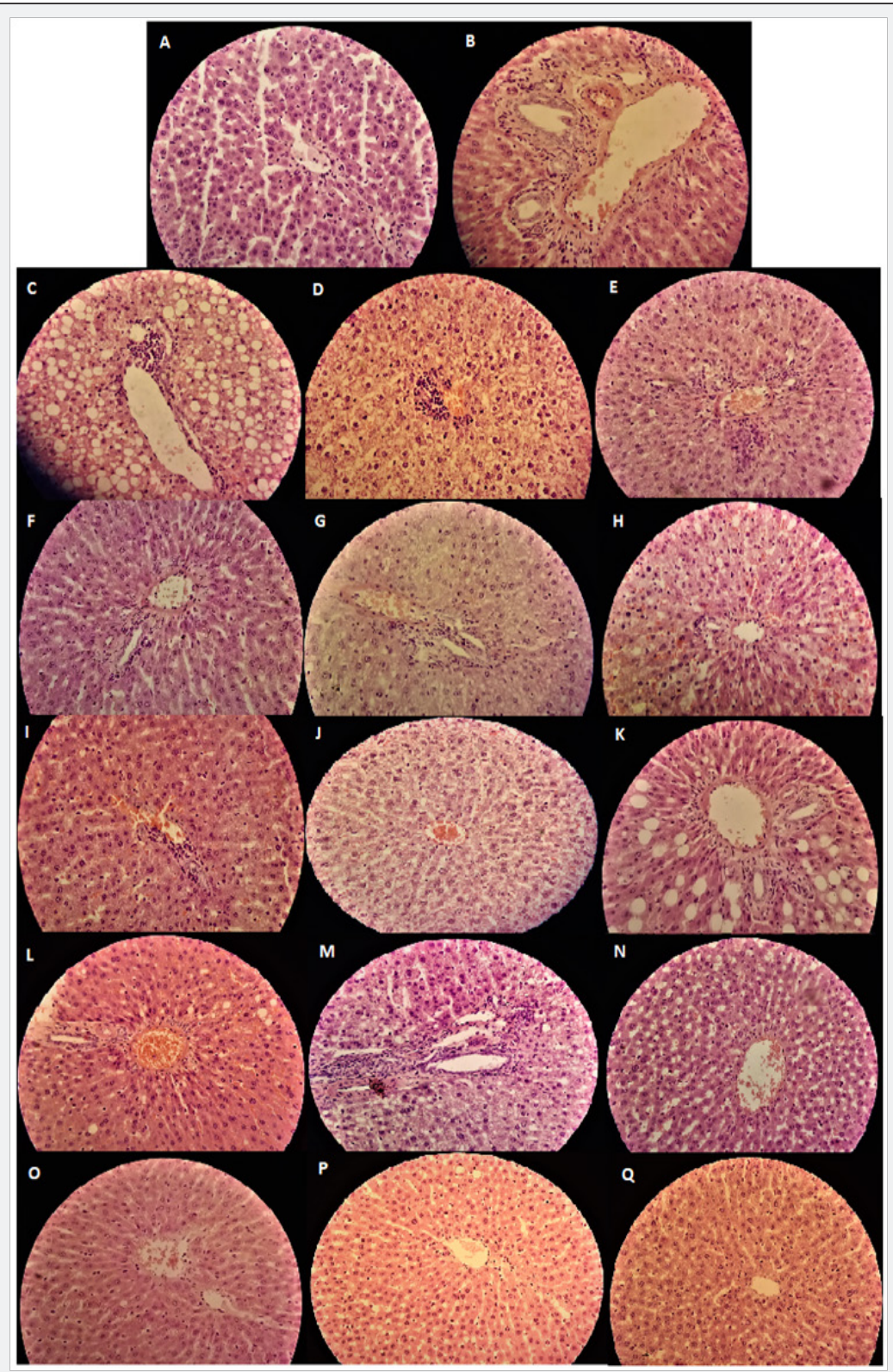

(A) Group I = normal control, (B) Group II = HFD control/atherogenic control, (C) Group III = HFD + $\mathrm{MgCO}_{3} 200 \mathrm{mg}$, (D) Group IV = HFD + $\mathrm{MgCO}_{3} 400 \mathrm{mg}$, (E) Group V = HFD + $\mathrm{MgCO}_{3} 600 \mathrm{mg}$, (F) Group VI = HFD + $\mathrm{CaCO}_{3} 500 \mathrm{mg}$, (G) Group VII = HFD + CaCO $1000 \mathrm{mg},(\mathrm{H})$ Group VIII = HFD + $\mathrm{CaCO}_{3} 1500 \mathrm{mg}$, (I) Group IX = HFD + $\mathrm{Ca}^{2+} 1000 \mathrm{mg}+\mathrm{Mg} 400 \mathrm{mg}$, (J) Group X = HFD + Ca ${ }^{2+} 500 \mathrm{mg}+\mathrm{Mg} 400 \mathrm{mg}$, (K) Group XI = HFD + $\mathrm{Ca}^{2+} 1500 \mathrm{mg}+\mathrm{Mg} 400 \mathrm{mg}$, (L) Group XII = HFD + $\mathrm{Ca}^{2+} 1000 \mathrm{mg}+\mathrm{Mg} 200 \mathrm{mg}$, (M) Group XIII = HFD + Ca ${ }^{2+} 500 \mathrm{mg}+$ Mg 200 mg, (N) Group XIV = HFD + Ca 1500mg + Mg 200 mg, (O) Group XV = HFD + Ca 1000 mg + Mg 600 mg, (P) Group XVI = HFD +Ca $500 \mathrm{mg}+\mathrm{Mg} 600 \mathrm{mg},(\mathrm{Q})$ Group XVII = HFD + Ca 1500mg + Mg 600mg. Each group was assessed at 400X magnification, scale bar: $40 \mu \mathrm{m}$. Figure 7: Effect of different dietary regimen (containing magnesium and calcium slats) on histological changes of liver tissue of rats after 12 week of study. 


\section{Discussion}

This has been evident for years that both magnesium and calcium play crucial roles in many of the body's physiological functions and induce competing effects on various chemical pathways. Many experimental studies have been done on hyperlipidemic animals in previous years which reported that calcium could be the mediator of the development of atherosclerosis while magnesium suppressed the development of atherosclerotic lesions in terms of lipid deposition in the aortic walls and the velocity of contraction of ventricular myocardium [45-48]. However, based on previous evidences regarding the effect of magnesium and calcium on the development of atherosclerosis, research have been continued till recent years to enumerate their impact not only on the development of atherosclerosis but also their effect on other important organs like liver and kidney $[21,34,49-52]$ since both of these elements play significant roles in the maintenance of our health. The present study, thereby, emphasized in understanding the effect of combined dose regimen of magnesium and calcium in diet of atherogenic rats. Our study revealed the effect of different combination doses of dietary magnesium and calcium on several parameters including body weight, systolic blood pressure, lipid profile and histology of aorta, kidney and liver of experimental rats after 12 weeks study period. These parameters helped to evaluate the development of atherosclerosis in animals and finally aided in perceiving the combined dose of dietary magnesium and calcium salts that could potentially reduce atherosclerotic lesions.

Based on changes in body weight, the results of the present study indicated that animals fed high- fat diet (Group II) increased body weight more than 200gm (with 108.33\% changes in body weight) after 12 weeks when compared with animals of any other groups including normal and treatment groups (Group I and Group III - Group XVII). However, the only group that showed very much similar result was Group XVII (220gm, with $100 \%$ changes in body weight) where dietary content of both magnesium and calcium salts were high (HFD + Ca 1500mg + Mg 600mg). Variation in changes of body weight in rats has been observed in cases of Mg- and Ca-deficient HFD. It was found that rats fed Mg-deficient HFD (Group VI - Group VIII) increased more weight ( $>210 \mathrm{gm})$ as compared with those fed with Ca-deficient HFD ( $<210$ gm, Group III - Group V). This indicated that dietary magnesium helped reduce development of obesity while calcium intake in HFD favored in rising body weight. A similar finding was observed in a study of previous year [53] where they showed that Mg-deficient diet significantly increased the body weight of rats with time. A more recent study by Bertinato et al. [54] revealed that low $\mathrm{Mg}$ diet reduced body weight gain in high-fat diet fed rats [54]. The understanding of this mechanism was reported by a number of studies [55-57] which stated that serum calcium level increased in animals (rats and mice) in response to moderate to severely low magnesium diet. This is because there is a competition between $\mathrm{Mg}$ and Ca for intestinal absorption and reabsorption in the kidney [58,59]. As a result increased serum calcium level raises calcium absorption and diminishes Mg antagonism [54]. This is associated increased PTH due to hyper activity of parathyroid gland resulting high body weight [60].

Many findings from the past years showed diversity in cardiac activities of the experimental animals based on magnesium and calcium intake. For instance, a study of 1984 by Stern et al. [61] revealed that high intake of calcium salt did not affect progression of hypertension in experimental animals [61]. A more recent research reported that low dietary intake of calcium benefits in controlling blood pressure. [34] On the other hand, study conducted by Laurant et al. [53] revealed that blood pressure of rats fed Mg-deficient diet was significantly higher than those fed control diet [53]. Similar report was found by Jin et al. [50] where systolic blood pressure of Mg-deficient diet fed rats was significantly high [51]. In our present investigation, the results revealed that high $\mathrm{Mg}$ diet (HFD + MgCO3 600mg) reduced Systolic Blood Pressure (SBP) to nearly normal $(112 \mathrm{mmHg})$. Similar result was found in high Ca diet (HFD + CaCO3 1500mg) where it reduced SBP to $115 \mathrm{mmHg}$. Such observation regarding high calcium diet in lowering blood pressure was found in a number of previous studies [61-64]. The plausible cause could be induction of negative sodium balance due to high serum calcium level that results in alteration in secretion of renin, aldosterone and catecholamines [65-68]. However, a study of Stanford University, USA in 2000 by Bostick et al. [69] found no effect of calcium supplementation on blood pressure during their clinical trial [69]. Besides, our results further revealed that systolic blood pressure of rats reduced between $100 \mathrm{mmHg}$ and $110 \mathrm{mmHg}$ when they were fed high $\mathrm{Mg}(600 \mathrm{mg})$ containing HFD with low to moderate dose of Ca salt $(500 \mathrm{mg}$ and $1000 \mathrm{mg}$; Group XV and Group XVI).

In addition, the results of the present study exhibited that high doses of both dietary magnesium (600mg) and calcium (1500mg) salts in high fat diet fed rats (Groups $V$ and VIII) significantly reduced serum cholesterol and LDL levels $(90 \pm 3.79 \mathrm{mg} / \mathrm{dl} ; 58 \pm 3.46 \mathrm{mg} / \mathrm{dl}$ and $93 \pm 3.46 \mathrm{mg} / \mathrm{dl} ; 55 \pm 2.31$ $\mathrm{mg} / \mathrm{dl}$ ) while the same doses significantly increased serum triglyceride levels $(78 \pm 4.04 \mathrm{mg} / \mathrm{dl}$ and $78 \pm 4.73 \mathrm{mg} / \mathrm{dl})$ in atherogenic rats. Similar observation regarding the effect of calcium supplementation on the fall of serum cholesterol level was found in the study by Bostick et al. [69] The biological reason for the plausible effects of calcium on lowering serum cholesterol level has been elucidated by several investigators in the past years considering the binding of calcium with bile acids to form insoluble soaps which may restrict cholesterol entering the gut via the enterohepatic circulation [70-75]. However, an investigation by Reid et al. [34] in 2010 revealed no significant effect of calcium supplementation on serum lipids (total triglycerides, cholesterol, LDL and HDL) in healthy men [34]. A more recent study by Gallo et al. [76] suggested that calcium significantly increased total cholesterol and triglyceride levels 
in their study population which contrast our present results regarding effect of calcium in rising serum triglyceride level [76]. This indicates a plausible association of calcium with a higher risk of cardiovascular disease. Interestingly, our study further revealed that different doses of magnesium and calcium salts in HFD (Group III - Group VI and Group VIII) have reduced serum HDL levels in atherogenic rats whereas it was significantly increased $(35 \pm 2.08 \mathrm{mg} / \mathrm{dl})$ when $1000 \mathrm{mg}$ of calcium salt has been incorporated in the high-fat diet (Group VII). A close association to this observation was found in the study of Gallo et al. [76] where the rise in serum HDL level due to calcium supplementation was seen along with other lipids [76]. Our present investigation found a close association to the fact that magnesium reduces the risk of developing atherosclerosis by lowering LDL cholesterol and rising HDL cholesterol [77] levels, since it acts as an essential cofactor for the rate-limiting enzyme in the sequence of biosynthesis of cholesterol [78]. However, it was also observed that magnesium in combination with calcium salts resulted better balance of body's lipid levels rather than magnesium salt alone in the atherogenic rats (Figure 2,3 \& 4) since the Groups XV and XVII (HFD + Ca1000 mg + Mg $600 \mathrm{mg}$ and HFD + Ca 1500mg + Mg 600mg) showed better control over serum free cholesterol levels and at the same time significantly reduced triglyceride and LDL levels while increased HDL level when compared with Ca-deficient groups that consumed different doses of magnesium salts in HFD (Groups III - V; Mg $200 \mathrm{mg} / 400 \mathrm{mg} / 600 \mathrm{mg}$ ).

Furthermore, our results of the biochemical parameters supported the histopathological changes of different organs including aorta, kidney and liver. Considerable deposition of lipid in these organs along with cellular infiltration was found in low magnesium diet (Group III). However, prominent accumulation of fat and morphological changes in the aortic wall involving destruction of smooth muscle cells, intimal cells, endothelial cells and fibroblast-like cells have been found in low to high doses of magnesium salt (Groups III - V). Besides, our results of biochemical tests demonstrated close relation to the report of histopathological examination of aorta of atherogenic rats of Groups XV (HFD + Ca1000mg + Mg 600 mg) and XVII (HFD + Ca $1500 \mathrm{mg}+\mathrm{Mg} 600 \mathrm{mg}$ ) showing less development of macrophagederived foam cells (MFC) with least degeneration of smooth muscle cells. This indicated that high doses of magnesium may have less protective effect against atherosclerosis unless moderate to high dose of calcium is consumed. Such observation has a very close association to an investigation from 1959 by Vitale et al. [27] and the recent statement of Dr. Russell Blaylock [22], who revealed, based on his research, that one must have an adequate intake of calcium when consuming sufficient magnesium in diet.

\section{Conclusion}

In conclusion, the present study demonstrated significant effect of low magnesium diet on the development of atherosclerosis and hypertension. High doses of both magnesium
(600 mg) and calcium salts (1500mg) helped to reduce systolic blood pressure in atherogenic rats (Groups V and VIII) while high calcium diet (i.e. Mg-deficient diet) resulted in progression of atherosclerosis by rising serum lipid levels. Although ideally magnesium supplementation has cardioprotective effect our present investigation, interestingly, showed that this effect was better achieved when magnesium was consumed in combination with calcium salt in the high-fat diet of experimental animals. After 12 weeks of study, Groups XV (HFD + Ca1000mg + Mg $600 \mathrm{mg}$ ) and XVII (HFD + Ca 1500mg + Mg 600mg) significantly reduced serum cholesterol, triglyceride and LDL levels while they increased the HDL level. At the same time, the systolic blood pressure of animals of these two groups was nearly normal. Furthermore, the histopathological report of aorta, kidney and liver of atherogenic rats of the same groups (Groups XV and XVII) demonstrated low to moderate atherosclerotic lesions, kidney lesions and liver steatosis. The results of the present study indicated that moderate to high dose of calcium salt $(1000 \mathrm{mg}-1500 \mathrm{mg}$ ) is required to facilitate the hypolipidemic effect of magnesium. Hence, our study supports a scientific rationale for the consumption of minimum $1000 \mathrm{mg}$ of calcium daily along with magnesium $(600 \mathrm{mg})$ in diet to reduce the risk of hypertension as well as to protect not only heart but also kidney and liver.

\section{Ethics approval}

All experimental procedures were approved by the Biomedical Research Center, University of Dhaka, Bangladesh.

\section{Consent for publication}

We confirm that this manuscript has not been published elsewhere and is not under consideration by another journal. All authors have approved the manuscript and agreed with submission to Open Access Journal of Toxicology

\section{Availability of data and materials}

All data generated or analyzed during this study are included in this published article

\section{Funding}

The present research was conducted for one year. The cost of research was high and no grant or departmental funding was received

\section{Author's contributions}

Rubaba Karim made substantial contributions to conception design and conduction of research. Tanjina Islam, Md. Shafiul Islam Khan, Sultana Jahan and Md. Masum Billah performed all of the experiments in the laboratory. Data collection, statistical analysis and interpretation were done by Rubaba Karim and Dr. Rayhana Begum. Article was written by Rubaba Karim and Ashfia Fatima Khan. Critical revision of the article was done by Dr. Rayhana Begum and Taslima Begum. All Authors read and approved the final manuscripts. 


\section{Acknowledgments}

Laboratory support from the Department of Pharmacy, Primeasia University, Dhaka, Bangladesh and Phytochemical Laboratory of University of Dhaka, Dhaka, Bangladesh is gratefully acknowledged. The authors also wish to acknowledge Prof. Dr. Md. Shah Amran (Department of Pharmaceutical Chemistry, University of Dhaka) for his technical support to complete this work.

\section{References}

1. Bentzon JF, Otsuka F, Virmani R, Falk E (2014) Mechanisms of plaque formation and rupture. Circulation research 114(12): 1852-1866.

2. Herrington W, Lacey B, Sherliker P, Armitage J, Lewington S (2016) Epidemiology of atherosclerosis and the potential to reduce the global burden of atherothrombotic disease. Circulation research 118(4): 535546.

3. (2017) World Health Organization, Cardiovascular diseases (CVDs), Fact Sheet.

4. Pearson TA, Blair SN, Daniels SR, Eckel RH, Fair JM, et al. (2002) AHA guidelines for primary prevention of cardiovascular disease and stroke: 2002 update. Circulation 106(3): 388-391.

5. Hegsted DM, McGandy RB, Myers ML, Stare FJ (1965) Quantitative effects of dietary fat on serum cholesterol in man. Am J Clin Nutr 17(5): 281-295.

6. Blumenthal HT, Lansing AI, Gray SH (1950) The interrelation of elastic tissue and calcium in the genesis of arteriosclerosis. The American journal of pathology 26(6): 989-1009.

7. Strickberger SA, Russek LN, Phair RD (1988) Evidence for increased aortic plasma membrane calcium transport caused by experimental atherosclerosis in rabbits. Circulation research 62(1): 75-80.

8. Campbell AK (1983) Intracellular calcium. Its universal role as a regulator.

9. Rembold CM, Murphy RA (1988) Myoplasmic [Ca2+] determines myosin phosphorylation in agonist-stimulated swine arterial smooth muscle. Circ Res 63(3): 593-603.

10. Hai C, Murphy RA (1989) Ca2+ crossbridge phosphorylation, and contraction. Annual review of physiology 51(1): 285-298.

11. Rosenblum IY, Flora L, Eisenstein R (1975) The effect of disodium ethane-1-hydroxy-1, 1-diphosphonate (EHDP) on a rabbit model of athero-arteriosclerosis. Atherosclerosis 22(3): 411-424.

12. Henry PD (1985) Atherosclerosis, calcium, and calcium antagonists Circulation 72(3): 456-459.

13. D’Angelo EK, Singer HA, Rembold CM (1992) Magnesium relaxes arterial smooth muscle by decreasing intracellular $\mathrm{Ca} 2+$ without changing intracellular Mg2+. J Clin Invest 89(6): 1988-1994.

14. Rasmussen HS, Norregard P, Lindeneg O, McNair P, Backer V, et al. (1986) Intravenous magnesium in acute myocardial infarction. The Lancet 327 (8475): 234-236.

15. Dyckner T, Wester PO (1983) Effect of magnesium on blood pressure. Br Med J (Clin Res Ed) 286(6381): 1847-1849.

16. Rosanoff A (2010) Magnesium supplements may enhance the effect of antihypertensive medications in stage 1 hypertensive subjects. Magnes Res 23(1): 27-40.

17. Houston M (2011) The role of magnesium in hypertension and cardiovascular disease. J Clin Hypertens (Greenwich) 13(11): 843-837.
18. Ouchi Y, Tabata RE, Stergiopoulos K, Sato F, Hattori A, et al. (1990) Effect of dietary magnesium on development of atherosclerosis in cholesterol-fed rabbits. Arteriosclerosis, Thrombosis, and Vascular Biology 10(5): 732-737.

19. Dawson EB, Frey MJ, Moore TD, McGanity WJ (1978) Relationship of metal metabolism to vascular disease mortality rates in Texas. The American journal of clinical nutrition 31(7): 1188-1197.

20. Hellerstein EE, Vitale JJ, White PL, Hegsted DM, Zamcheck N, et al. (1957) Influence of dietary magnesium on cardiac and renal lesions of young rats fed an atherogenic diet. The Journal of experimental medicine 106(5): 767-776.

21. Tashiro M, Inoue H, Konishi M (2013) Magnesium homeostasis in cardiac myocytes of Mg-deficient rats. PloS one 8(9): e73171.

22. Russell Blaylock (2015) Low Magnesium Hardens Arteries. Newsmax Health.

23. Davis WH (1984) Mono-therapy with magnesium increases abnormally low high density lipoprotein cholesterol: a clinical assay. Curr Ther Res Clin Exp 36: 341-346.

24. Rasmussen HS, Aurup P, Goldstein K, McNair P, Mortensen PB, et al (1989) Influence of magnesium substitution therapy on blood lipid composition in patients with ischemic heart disease: a double-blind, placebo controlled study. Archives of Internal Medicine 149(5): 10501053.

25. Singh RB, Rastogi SS, Sharma VK, Saharia RB, Kulshretha SK (1990) Can dietary magnesium modulate lipoprotein metabolism? Magnes Trace Elem 9(5): 255-264.

26. Corica F, Allegra A, Di Benedetto A, Giacobbe MS, Romano G, et al. (1994) Effects of oral magnesium supplementation on plasma lipid concentrations in patients with non-insulin-dependent diabetes mellitus. Magnesium research 7(1): 43-47.

27. Vitale JJ, Hellerstein EE, Hegsted DM, Nakamura M, Farbman A (1959) Studies on the interrelationships between dietary magnesium and calcium in atherogenesis and renal lesions. The American journal of clinical nutrition 7(1): 13-22.

28. Lichtenstein AH, Appel LJ, Brands M, Carnethon M, Daniels S, et al. (2006) Diet and lifestyle recommendations revision 2006. Circulation 114(1): 82-96.

29. McGuire S (2011) US Department of Agriculture and US Department of Health and Human Services, Dietary Guidelines for Americans, 2010. Washington, DC: US Government Printing Office, January 2011. Advances in Nutrition: An International Review Journal 2(3): 293-294.

30. Moghadasian MH, Frohlich JJ, McManus BM (2001) Advances in experimental dyslipidemia and atherosclerosis. Laboratory Investigation 81(9): 1173-1183.

31. Moghadasian MH (2002) Experimental atherosclerosis: a historical overview. Life Sci 70(8): 855-865.

32. Lichtman AH, Clinton SK, Iiyama K, Connelly PW, Libby P, et al. (1999) Hyperlipidemia and atherosclerotic lesion development in LDL receptor-deficient mice fed defined semipurified diets with and without cholate. Arterioscler Thromb Vasc Biol 19(8): 1938-1944.

33. Matos SL, Paula HD, Pedrosa ML, Santos RC, Oliveira EL, et al. (2005) Dietary models for inducing hypercholesterolemia in rats. Brazilian Archives of Biology and Technology 48(2): 203-209.

34. Reid IR, Ames R, Mason B, Bolland MJ, Bacon CJ, et al. (2010) Effects of calcium supplementation on lipids, blood pressure, and body composition in healthy older men: a randomized controlled trial. The American journal of clinical nutrition 91(1): 131-139. 
35. Nair AB, Jacob S (2016) A simple practice guide for dose conversion between animals and human. Journal of basic and clinical pharmacy $7(2): 27-31$.

36. Nishiyama S, Nakamura K, Konishi Y (1986) Blood pressure and urinary sodium and potassium excretion in cadmium-treated male rats. Environmental research 40(2): 357-364.

37. Roeschlau P, E Bernt, JW Gruber (1974) Clinical Chemistry and Clinical Biochemistry pp. 403-405.

38. Tietz NW (1990) Serum triglyceride determination. Clinical guide to laboratory tests 2: 554-556.

39. Burstein MS, Scholnick HR, Morfin R (1970) Rapid method for the isolation of lipoproteins from human serum by precipitation with polyanions. Journal of lipid research 11(6): 583-595.

40. Jia YJ, Liu J, Guo YL, Xu RX, Sun J, et al. (2013) Dyslipidemia in rat fed with high-fat diet is not associated with PCSK9-LDL-receptor pathway but ageing. J Geriatr Cardiol 10(4): 361-368.

41. Braunwald E (1988) Coronary blood flow and myocardial ischemia Heart disease, a textbook of cardiovascular medicine. pp. 1191-221.

42. Small DM (1988) George Lyman Duff memorial lecture. Progression and regression of atherosclerotic lesions. Insights from lipid physical biochemistry. Arteriosclerosis, Thrombosis, and Vascular Biology 8(2): 103-129.

43. Römer TJ, Brennan JF, Fitzmaurice M, Feldstein ML, Deinum G, et al. (1988) Histopathology of human coronary atherosclerosis by quantifying its chemical composition with Raman spectroscopy. Circulation 97(9): 878-885.

44. Yuan Y, Li P, Ye J (2012) Lipid homeostasis and the formation of macrophage-derived foam cells in atherosclerosis. Protein \& cell 3(3): 173-181.

45. Willis AL, Nagel B, Churchill V, Whyte MA, Smith DL, et al. (1985) Antiatherosclerotic effects of nicardipine and nifedipine in cholesterolfed rabbits. Arteriosclerosis, Thrombosis, and Vascular Biology 5(3): 250-255.

46. Watanabe N, Ishikawa Y, Okamoto R, Watanabe Y, Fukuzaki H (1987) Nifedipine suppressed atherosclerosis in cholesterol-fed rabbits but not in Watanabe heritable hyperlipidemic rabbits. Artery 14(5): 283 294

47. Vierling W, Ebner F, Reiter M (1978) The opposite effects of magnesium and calcium on the contraction of the guinea-pig ventricular myocardium in dependence on the sodium concentration. NaunynSchmiedeberg's archives of pharmacology 303(2): 111-119.

48. Orimo H, Ouchi Y (1990) The role of calcium and magnesium in the development of atherosclerosis. Annals of the New York Academy of Sciences 598(1): 444-457.

49. Khan SR, Glenton PA (2008) Calcium oxalate crystal deposition in kidneys of hypercalciuric mice with disrupted type IIa sodiumphosphate cotransporter. American Journal of Physiology-Renal Physiology 294(5): F1109-F1115.

50. Jin K, Kim TH, Kim YH, Kim YW (2013) Additional antihypertensive effect of magnesium supplementation with an angiotensin II receptor blocker in hypomagnesemic rats. The Korean journal of internal medicine 28(2): 197-205.

51. Al Hakeim HK (2009) Serum levels of lipids, calcium and magnesium in women with hypothyroidism and cardiovascular diseases. Journal of laboratory physicians 1(2): 49.

52. Lutsey PL, Alonso A, Michos ED, Loehr LR, Astor BC, et al. (2014) Serum magnesium, phosphorus, and calcium are associated with risk of incident heart failure: the Atherosclerosis Risk in Communities (ARIC) Study. The American journal of clinical nutrition 100(3): 756-764.

53. Laurant P, Hayoz D, Brunner HR, Berthelot A (1999) Effect of magnesium deficiency on blood pressure and mechanical properties of rat carotid artery. Hypertension 33(5): 1105-1110.

54. Bertinato J, Lavergne C, Rahimi S, Rachid H, Vu NA, et al. (2016) Moderately low magnesium intake impairs growth of lean body mass in obese-prone and obese-resistant rats fed a high-energy diet. Nutrients 8(5): 253

55. Rude RK, Gruber HE, Wei LY, Frausto A, Mills BG (2003) Magnesium deficiency: effect on bone and mineral metabolism in the mouse. Calcified tissue international 72(1): 32-41.

56. Rude RK, Gruber HE, Norton HJ, Wei LY, Frausto A, et al. (2004) Bone loss induced by dietary magnesium reduction to $10 \%$ of the nutrient requirement in rats is associated with increased release of substance $\mathrm{P}$ and tumor necrosis factor- $\alpha$. J Nutr 134(1): 79-85.

57. Jones JE, Schwartz R, Krook L (1980) Calcium homeostasis and bone pathology in magnesium deficient rats. Calcified tissue international 31(1): 231-238.

58. Alcock N, MacIntyre I (1962) Inter-relation of calcium and magnesium absorption. Clinical science 22: 185-193.

59. Bertinato J, Lavergne C, Plouffe LJ, El Niaj HA (2014) Small increases in dietary calcium above normal requirements exacerbate magnesium deficiency in rats fed a low magnesium diet. Magnesium Research 27(1): 35-47.

60. Bolland MJ, Grey AB, Gamble GD, Reid IR (2005) Association between primary hyperparathyroidism and increased body weight: a metaanalysis. The Journal of Clinical Endocrinology \& Metabolism 90(3): 1525-1530.

61. Stern N, Lee DB, Silis V, Beck FW, Deftos L, et al. (1984) Effects of high calcium intake on blood pressure and calcium metabolism in young SHR. Hypertension 6(5): 639-646.

62. Mccarron DA, Yung NN, Ugoretz BA, Krutzik S (1981) Disturbances of calcium metabolism in the spontaneously hypertensive rat. Hypertension 3(3 Pt 2): I162.

63. Ayachi S (1979) Increased dietary calcium lowers blood pressure in the spontaneously hypertensive rat. Metabolism 28(12): 1234-1238.

64. Belizan JM, Villar J, Pineda O, Gonzalez AE, Sainz E, et al. (1983) Reduction of blood pressure with calcium supplementation in young adults. Jama 249(9): 1161-1165.

65. Brinton GS, Jubiz W, Lagerquist LD (1975) Hypertension in primary hyperparathyroidism: the role of the renin-angiotensin system. The Journal of Clinical Endocrinology \& Metabolism 41(6): 1025-1029.

66. Foster R, Lobo MV, Rasmussen H, Marusic ET (1981) Calcium: its role in the mechanism of action of angiotensin II and potassium in aldosterone production. Endocrinology 109(6): 2196-2201.

67. Romoff MS, Keusch G, Campese VM, Wang MS, Friedler RM, et al. (1979) Effect of sodium intake on plasma catecholamines in normal subjects. The Journal of Clinical Endocrinology \& Metabolism 48(1): 26-31.

68. Hahn SA, Shneidman RJ, McCarron DA (1984) Prevention of GeneticHypertension In the Shr-Concurrent Effects Of $\mathrm{Na}+$ And Ca2+. Inclinical Research 32(1): A36-A36.

69. Bostick RM, Fosdick L, Grandits GA, Grambsch P, Gross M, et al. (2000) Effect of calcium supplementation on serum cholesterol and blood pressure: a randomized, double-blind, placebo-controlled, clinical trial. Archives of family medicine 9(1): 31-38. 
70. Newmark HL, Wargovich MJ, Bruce WR (1984) Colon cancer and dietary fat, phosphate, and calcium: a hypothesis. Journal of the National Cancer Institute 72(6): 1323-1325.

71. Fleischman AI, Yacowitz H, Hayton T, Bierenbaum ML (1966) Effects of dietary calcium upon lipid metabolism in mature male rats fed beef tallow. Journal of Nutrition 88(3): 255-260.

72. Yacowitz H, Fleischman AI, Amsden RT, Bierenbaum ML (1967) Effects of dietary calcium upon lipid metabolism in rats fed saturated or unsaturated fat. Journal of Nutrition 92(3): 389-392.

73. Fleischman AI, Bierenbaum ML, Lenz PH (1972) The hypolipidemic effect of calcium-containing compounds and vitamin D 2 in the rat. Lipids 7(4): 263-266.

74. Renaud S, Ciavatti M, Thevenon C, Ripoll JP (1983) Protective effects of dietary calcium and magnesium on platelet function and atherosclerosis in rabbits fed saturated fat. Atherosclerosis 47(2): 187-198.

75. Bhattacharyya AK, Thera C, Anderson JT, Grande F, Keys A (1969) Dietary calcium and fat. Effect on serum lipids and fecal excretion of cholesterol and its degradation products in man. American Journal of Clinical Nutrition 22(9): 1161-1174.

76. Gallo L, Faniello MC, Canino G, Tripolino C, Gnasso A, et al. (2016) Serum Calcium Increase Correlates With Worsening of Lipid Profile: An Observational Study on a Large Cohort From South Italy. Medicine 95(8): e2774.

77. Seelig MS, Rosanoff A (2003) The magnesium factor. Penguin pp. 384.

78. Rosanoff A, Seelig MS (2004) Comparison of mechanism and functional effects of magnesium and statin pharmaceuticals. J Am Coll Nutr 23(5): 501S-505S.

\section{Your next submission with Juniper Publishers will reach you the below assets}

- Quality Editorial service

- Swift Peer Review

- Reprints availability

- E-prints Service

- Manuscript Podcast for convenient understanding

- Global attainment for your research

- Manuscript accessibility in different formats

( Pdf, E-pub, Full Text, Audio)

- Unceasing customer service

Track the below URL for one-step submission https://juniperpublishers.com/online-submission.php 